Journal of the Statistical and Social Inquiry Society of Ireland

Vol. XL

\title{
The Economic and Fiscal Contribution of US Investment in Ireland
}

\author{
Keith Walsh* \\ Office of the Revenue Commissioners
}

(read before the Society, 9 December 2010)

\begin{abstract}
Multinational companies from the United States of America are important sources of foreign investment in Ireland. The role of these companies in the Irish economy has been previously documented and is reviewed briefly. The main contribution of this paper is to present for the first time data on the fiscal impact of US companies in Ireland. The results show that US companies are significant sources of tax revenue. Over the last decade US companies have consistently paid around one third of the annual corporation tax revenue collected in Ireland. US companies also make large payments of value added tax, excise duty and income tax - the latter is due to the approximately one hundred thousand people employed in Ireland by US companies and indicates the substantial nature of US investment in this country. The sectoral composition of tax revenue from US companies and employment patterns over time are also examined.
\end{abstract}

Keywords: foreign direct investment, Unites States, fiscal policy, Ireland

JELs: E22, E62, F21

\section{INTRODUCTION}

It is well known that Ireland is an exceptionally open economy relative to its size. Whether measuring investment flows or exports and imports of goods and services, Ireland is ranked as one of the most open economies in the European Union (EU) or the OECD (Forfás, 2010).

Ireland's openness to investment is also seen when comparing the number of jobs created by foreign investment across countries. IBM (2010) ranked Ireland as first in the world in terms of job creation by foreign investment relative to population size.

Investment in Ireland by multinational companies from the United States of America is substantial. This represents the continuation of an economic relationship that has existed for several decades. Multinational companies are attracted to locate operations in Ireland by a range of factors and US companies are strongly represented among them. In addition to standard investment location factors, such as regulatory environment, workforce skills, costs, infrastructure and tax policy, US companies are also attracted to Ireland by an English-speaking population, EU membership that allows Ireland to provide an export platform to supply markets in Europe and Ireland's large network of tax treaties.

Despite the importance of US investment in Ireland, it is difficult to measure the size of the contribution of US multinational companies accurately. A range of data sources exists but they are of varying usefulness. This paper briefly reviews some of existing literature and data on the economic aspects of US multinational investment in Ireland. However, the focus of the paper is to examine in detail the fiscal contribution of US companies. This is possible using Revenue data on tax payments and returns. Analysing data on the major taxes, sectoral composition and changes over time provides a clear picture of the fiscal contribution of US companies to the Irish economy for the first time.

\footnotetext{
* Economist, Research and Analytics Branch, Office of the Revenue Commissioners (keithw@,revenue.ie). The author is grateful to Eamonn O'Dea, Michael O'Grady, Norman Gillanders and colleagues from the Research and Analytics Branch for their comments. All opinions expressed in this paper are the views of the author and do not reflect the views of the Office of the Revenue Commissioners. The author alone is responsible for the conclusions.
} 
The paper is structured as follows. Section 2 examines the overall international investment position in Ireland and the economic role of inward investment from the US to give some context for following sections. Section 3 briefly summarises the methodology used to identify US companies in Ireland. Section 4 examines the fiscal contribution of US companies under a number of headings (corporation tax, VAT, excise duty, income tax, and employment) and compares the results to existing studies. The final section concludes.

\section{THE ECONOMIC CONTRIBUTION OF US INVESTMENT IN IRELAND}

\subsection{The Stock and Flow of International Investment in Ireland}

To place US investment in Ireland in context, it is useful to provide an overview of Ireland's overall international investment position. International investment has played a significant role in the development of the Irish economy. Figure 1 shows the stock of inward and outward investment in Ireland. While Ireland's inward stock of international investment receives considerable attention, the size of the outward stock is almost as large. Ireland's net international investment position has been slightly negative since 2000 (i.e., inward exceeded outward investment). The inward investment stock was valued at $€ 2,460$ bn at the end of 2009, Ireland's Gross Domestic Product (GDP) for that year was around $€ 160$ bn.

Figure 1: Ireland's International Investment Stock 1998 to 2009

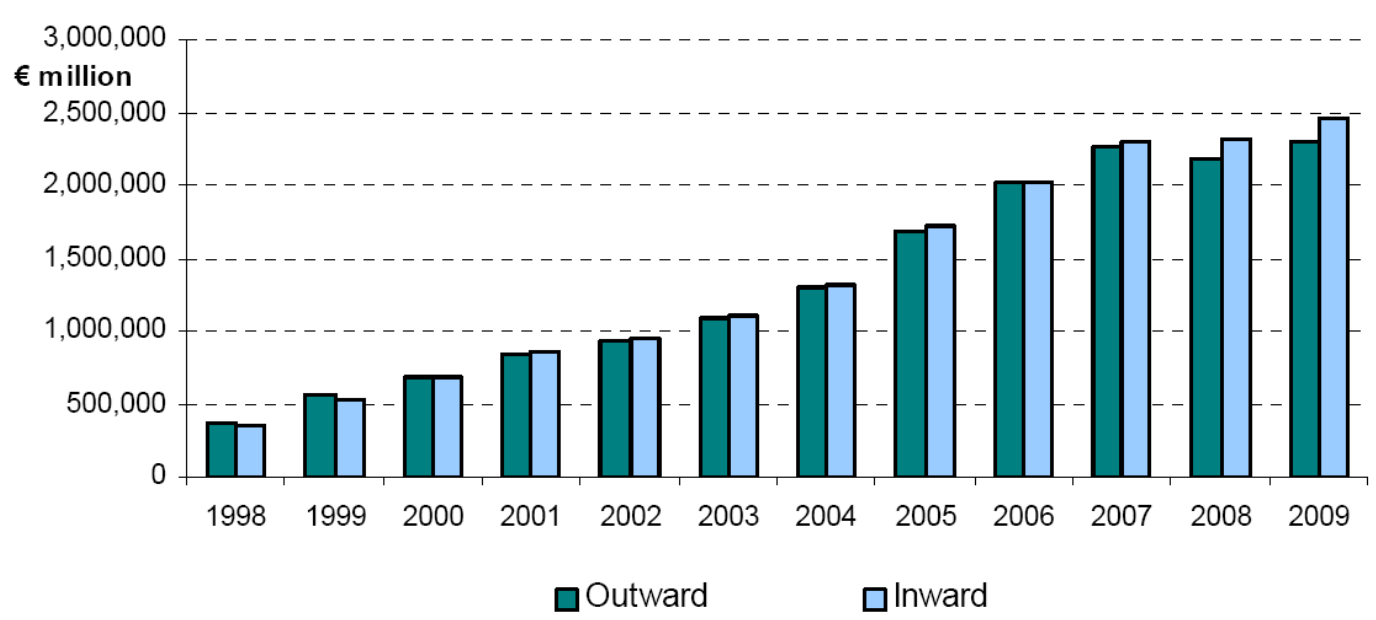

Source: CSO data. Foreign assets and liabilities represent outward and inward investment stocks respectively.

Looking at flows in 2009, rather than the overall stock discussed above, Ireland's balance of payments on the current account is negative, despite a large surplus in merchandise trade, due to deficits on services trade and income. ${ }^{1}$ The balance on the financial account is in deficit in 2009, as the liabilities (or obligations) of Irish residents to foreign investors are greater than the claims on foreign assets by Irish residents.

Figure 2 shows the disaggregation of inward investment from Figure 1 (the situation for outward investment is similar but the focus of this paper is inward investment). Figure 2A classifies the inward investment stock into IFSC (International Financial Services Centre) and non-IFSC investment. The large role of the IFSC is clear. While non-IFSC investment is of the more "traditional" industrial nature, much of the inward IFSC investment involves the movement of capital by multinational companies to subsidiaries in the IFSC that is re-invested overseas - as a result inward and outward IFSC investment are relatively equal and have little impact on the domestic economy (Barry and O’Mahony, 2004).

\footnotetext{
${ }^{1}$ Income in the current account context is income earned on investment (such as dividends on equity investments) and interest on loans and other financial transactions. The deficit in the Irish case reflects that income of foreign investors in Ireland is greater than the income earned by Irish investors abroad.
} 
An alternative breakdown of the stock of inward investment is shown in Figure 2B. Direct investment is investment in the equity of an enterprise that results in a controlling interest. When foreign direct investment (FDI) is discussed, it is usually taken to refer to this type of direct investment. ${ }^{2}$ Portfolio investment, which has grown considerably in Ireland due to the role of IFSC, is the acquisition (or disposal) of equity and debt where there is no controlling influence of the investor. ${ }^{3}$ The "other" investment category has also expanded in recent years, this includes loans, currency, deposits and other financial instruments including derivatives.

Figure 2: Composition of Inward International Investment Stock in Ireland 1998 to 2009

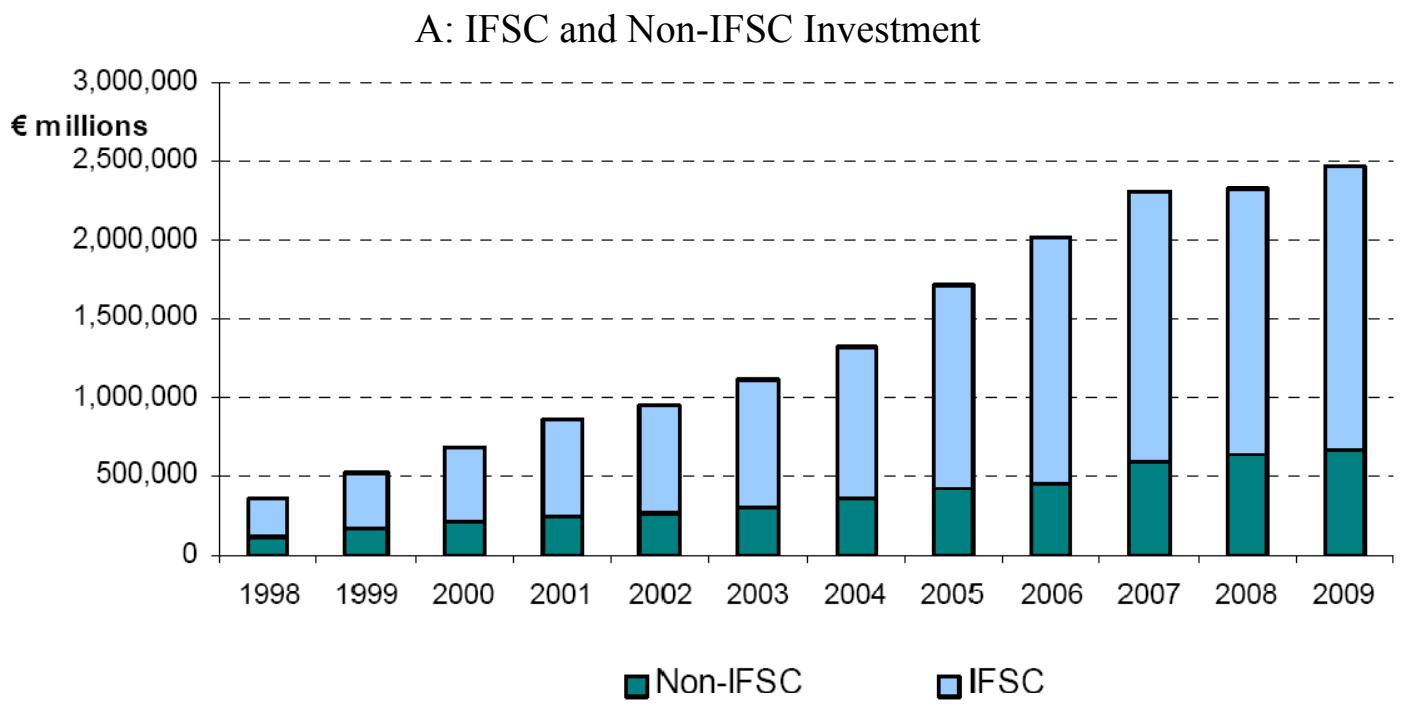

B: Investment Type

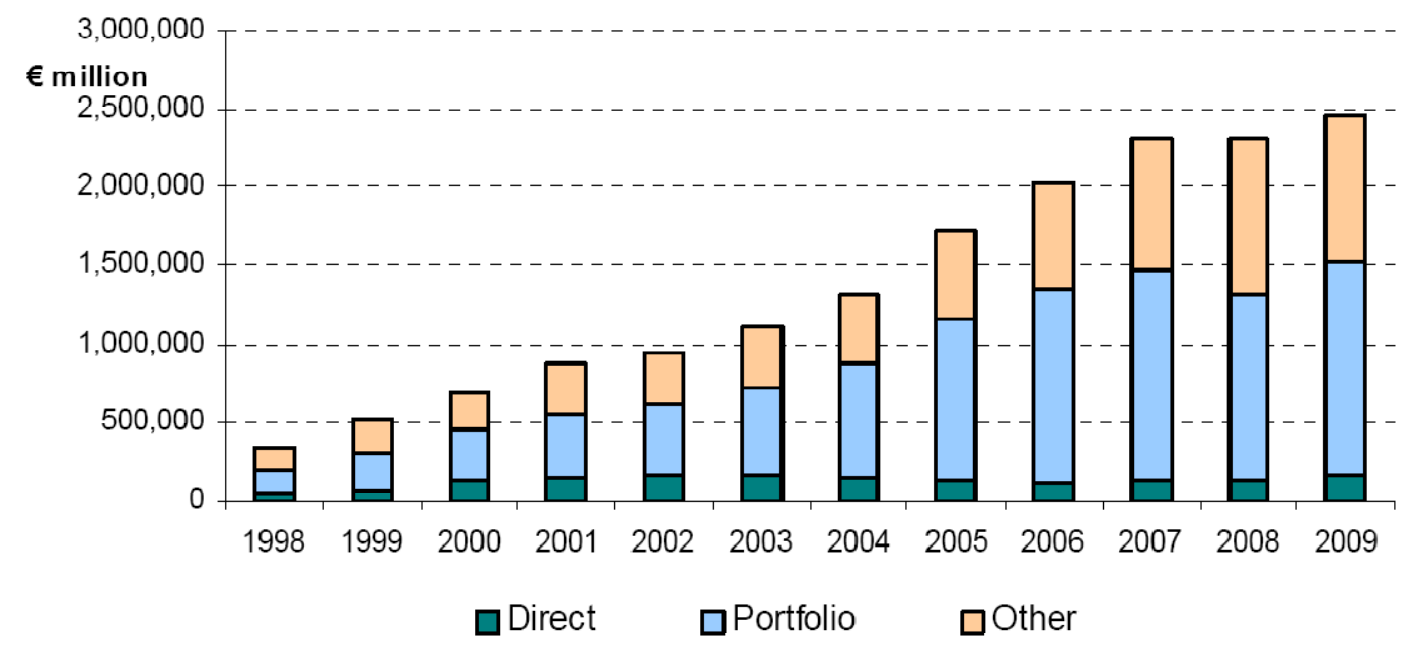

Source: CSO data.

\footnotetext{
${ }^{2}$ For example, comparisons of "openness" to investment between countries are usually based on direct investment from abroad. Ireland's stock of direct investment was equal to around 65 per cent of GDP in 2008, down from a high of nearly 150 per cent in 2000 but it remains among the highest in the EU or the OECD (Forfas, 2010).

${ }^{3}$ A 10 per cent ownership threshold is typically applied to differentiate between direct and portfolio investment.
} 


\subsection{Overall US Investment in Ireland}

Ireland has received substantial investment from the US. The Industrial Development Agency (IDA, 2010) reports that 471 IDA-supported companies of US origin operated in Ireland in 2009 - about 50 per cent of the total number of IDA-supported companies. Data from the US Bureau of Economic Analysis (BEA) suggest about 550 affiliates of US companies operate in Ireland. The American Chamber of Commerce Ireland (2010) estimate is over 580. Significant investment goes in the other direction also, around 200 Irish companies are estimated to have operations in the US.

US investment stock in Ireland was valued at $€ 122 \mathrm{bn}$ in 2009 (BEA). Figure 3 shows the share of global outward US investment stock in Ireland since the early 1980s. The share has increased substantially, in particular in the last ten years and is now well over 4 per cent. Ireland's share of the world's population is 0.06 per cent and the Irish economy accounts for less than 0.5 per cent of global GDP. Clearly, Ireland performs well in terms of attracting US investment relative to size and is one the largest recipients in Europe in absolute terms.

Figure 3: Share of US Global Outward Investment Stock in Ireland 1982 to 2009

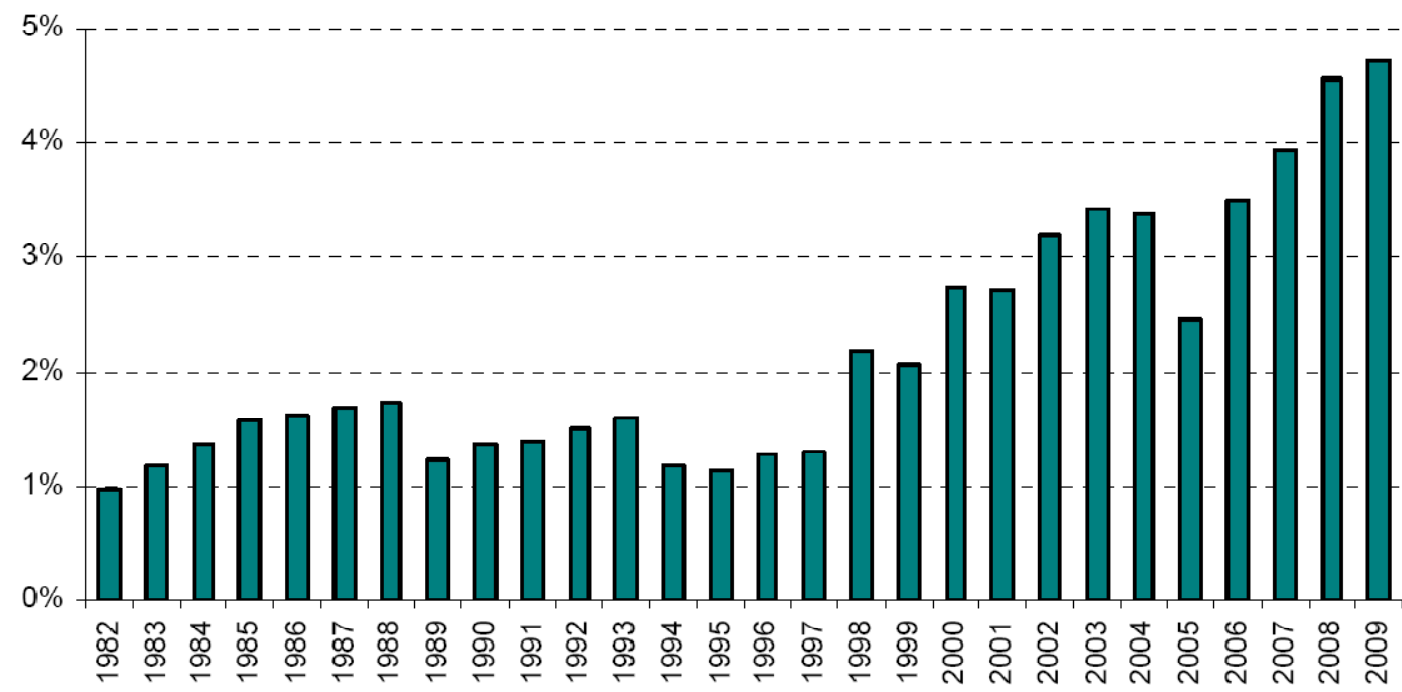

Source: BEA data and author's calculations.

Table 1 shows the geographic breakdown of two components of Ireland's inward investment stock direct and portfolio investment. ${ }^{4}$ Table 1 indicates that the largest source of investment is the Eurozone group of countries followed by the UK and the US. However, the origin country in Table 1 is based on the location of the immediate owner of the company rather than that of the ultimate beneficial owner. For example, investment by a US company in Ireland via a subsidiary in a third country would be classified as investment from the third country. Lane and Ruane (2006) report that, based on ultimate beneficial ownership, 54 per cent of direct investment into Ireland originated in the US and 24 and 11 per cent from the UK and rest of EU respectively. ${ }^{5}$

Table 1: Source of Inward Direct and Portfolio Investment Stocks in Ireland

\begin{tabular}{lcc}
\hline \multicolumn{1}{c}{ Origin Country } & Direct Investment & Portfolio Investment \\
\hline & & \\
\hline United Kingdom & $11 \%$ & $17 \%$ \\
United States & $9 \%$ & $10 \%$ \\
Eurozone & $59 \%$ & $53 \%$ \\
Rest EU & $2 \%$ & $2 \%$ \\
Rest of World & $19 \%$ & $17 \%$ \\
All Countries & $100 \%$ & $100 \%$
\end{tabular}

Source: CSO (DI) and IMF (PI) data and author's calculations. Figures are the three year average (2007 to 2009 for DI and 2006 to 2008 for PI).

\footnotetext{
${ }^{4}$ A breakdown for "other", the third category in Figure 2B, is not available. While it is unfortunate that the "other" investment category is not broken down, it relates more to financial transactions than more traditional investment flows and therefore may not be as closely linked to production or employment.

${ }^{5}$ This is based on earlier CSO analysis and relates to the period 2001 to 2003.
} 


\subsection{Sectoral Distribution of US Investment in Ireland}

There are several sources of data on the sectoral distribution of foreign investment in Ireland, however all are limited with respect to estimating the sectoral spread of US companies. For example, the published data in the most detailed CSO sources, such as the Census of Industrial Production, provide ownership breakdowns by Irish or foreign but do not provide sufficient information to separate out US companies. Similarly, the Forfás Annual Business Survey of Economic Impact reports on a number of topics for IDA and other supported companies in Ireland but the published data only distinguish the results between domestic or foreign. The following sections analyse the sectoral distribution of US companies under a number of headings (investment, value added, trade and employment) using a variety of data as no single source provides a complete picture. ${ }^{6}$

\subsubsection{Direct Investment in Ireland}

Figure 4 shows the distribution of US direct investment in Ireland by sector from the US BEA data. ${ }^{7}$ The largest sectors are finance, holding company activity and information. The information sector includes many communication activities and data processing and storage services. Ireland receives 16.7 per cent of global US outward investment in this sector and 17 per cent of US investment in the professional and technical services sector. It is worth noting that the data show investment in sectors such as finance and holding company activity to be quite volatile year to year.

Figure 4: US Direct Investment in Ireland by Sector

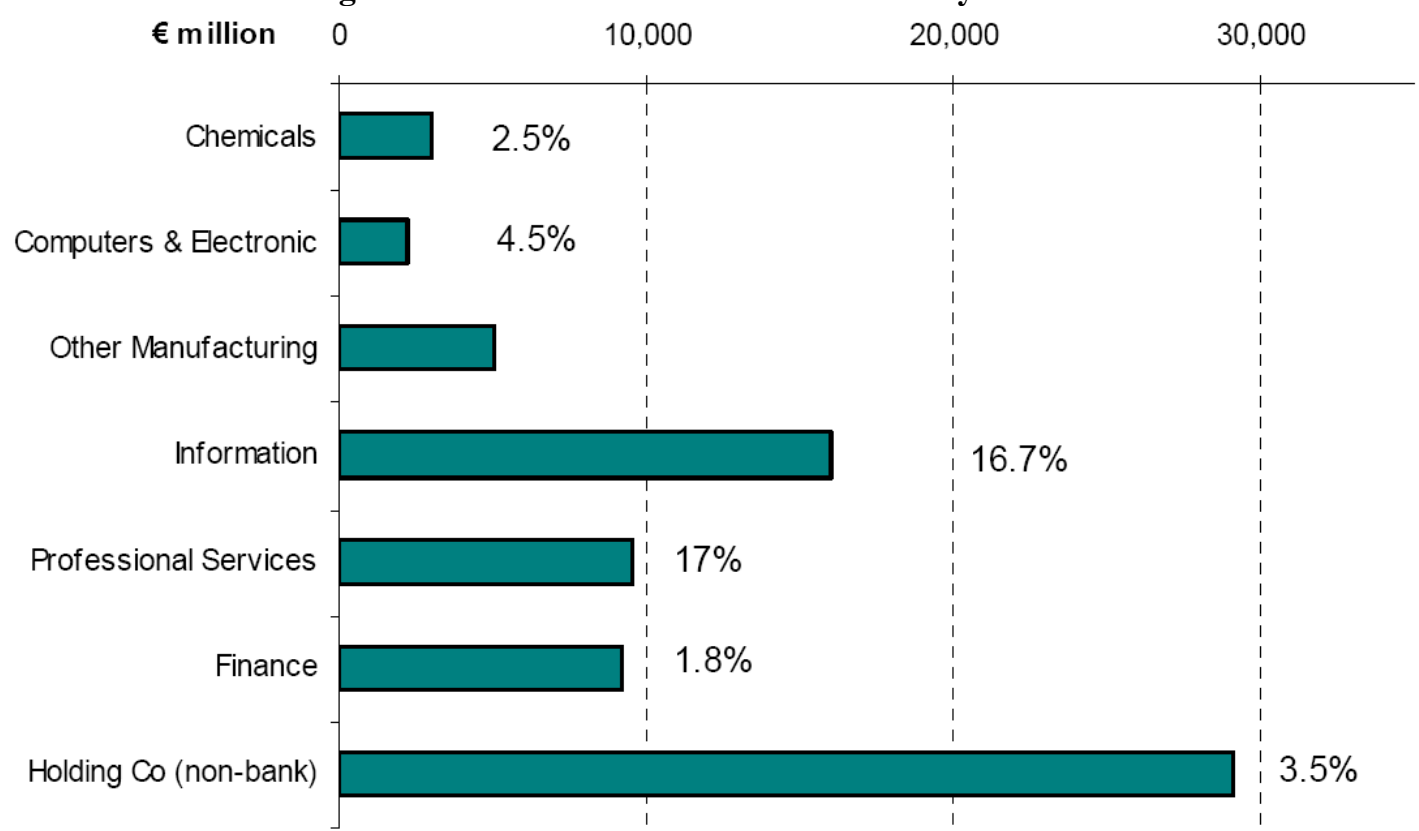

Source: BEA data and author's calculations. Percentages next to the bars show the share of total world investment from the US located in Ireland by sector (not shown for other manufacturing as it is calculated as a residual). The data show the three year average for 2007 to 2009.

\subsubsection{Value-Added of US Companies in Ireland}

The value-added (broadly defined as total output less intermediate inputs by sector) as reported by the BEA for US companies in Ireland indicates the size of their contribution to Irish output. The data are shown in Table 2. The largest sector in terms of value-added is chemicals (this includes many pharmaceutical-related activities). The total figure, $€ 38.7 \mathrm{bn}$, is equal to almost one fifth of Irish GDP or a quarter of GNP. ${ }^{89}$ This represents a very substantial contribution to output in the Irish economy.

\footnotetext{
${ }^{6}$ A note of caution when reading the following sections: the sectoral classifications used vary and in some cases similarly named sectors may not cover the same activities. CSO data tend to follow the NACE classification but in some cases data are only available at a broad level. BEA data are based on the NAIC - a North American classification.

${ }_{8}^{7}$ BEA data are discussed in more detail in Section 4.5.

${ }^{8}$ Care should be taken with some BEA data, as certain figures may be overestimates. For example, the BEA reports total sales by US affiliates based in Ireland in 2008 was $€ 170 \mathrm{bn}$ but according to Forfás (2009) data, total sales for all foreign companies in 2008 was $€ 115$ bn (not all of which would be US companies). Value-added by US affiliates in the BEA was €39bn compared to €50bn in Forfás (2009) for all foreign companies. Bearing these figures in mind, the sector shares in Table 2 are still useful to focus on the relative sizes of investment.
} 
Table 2: Value-Added by Sector of US Companies in Ireland

\begin{tabular}{lcc}
\hline \multicolumn{1}{c}{ Sector } & $\begin{array}{c}\text { Value-Added } \\
\text { (€ million) }\end{array}$ & \% \\
\hline Food & 265 & $0.7 \%$ \\
\hline Chemicals & 10,360 & $26.7 \%$ \\
Computers \& electronic products & 4,374 & $11.3 \%$ \\
Electrical equipment, appliances \& components & 114 & $0.3 \%$ \\
Other manufacturing & 5,855 & $15.1 \%$ \\
Wholesale trade & 4,201 & $10.8 \%$ \\
Infornation & 3,329 & $8.6 \%$ \\
Finance & 143 & $0.4 \%$ \\
Professional services & 1,226 & $3.2 \%$ \\
Other & 8,864 & $22.9 \%$ \\
All Sectors & 38,731 & $100.0 \%$
\end{tabular}

Source: BEA data and author's calculations. Figures are three year average for 2006 to 2008 . The data related to 2008 are preliminary and may be revised.

\subsubsection{Trade Linkages between Ireland and the US}

The initial phase of Ireland's economic growth in the 1990s was export focused. Much of the growth in that period was driven by multinational companies establishing operations in Ireland to supply markets elsewhere. In merchandise goods Ireland runs a large trade surplus as shown in Figure 5A. The Figure shows imports and exports for eight categories of goods. In each case the breakdown of the imports and exports between the US and the rest of the world is shown. In total almost 20 per cent of Irish goods exports are destined for the US and 12 per cent of imports originate there.

The chemicals and related goods (including pharmaceuticals) sector and the machinery and transport equipment sector (this sector covers a wide range of manufacturing activities) account for the largest shares of Irish merchandise goods exports. Goods from the machinery and transport sector are the only large source of imports, most likely driven by the import of materials by multinational companies for use as intermediate inputs in the production of goods for export. Around a third of world trade is estimated to occur within multinational companies (OECD, 2002) and such activity is likely to contribute significantly to Ireland's external trade, in particular on the import side.

Figure 5A shows that the US as a destination accounts for only a small share of the export market. Most multinational companies that operate in Ireland, including US-owned companies, are supplying the European market (and also African and Asian markets in some cases) and so Europe accounts for the largest share of export destinations. It is likely that US-owned companies are the producers of a large share of merchandise goods exported from Ireland.

On services trade, the picture in Figure 5B is more mixed. Services trade is smaller in absolute terms than merchandise trade but growing quickly in Ireland. This follows the global pattern that has seen services trade expand rapidly in recent years. Ireland is a net importer of services but the deficit is small relative to the export surplus in merchandise goods. For services trade in total, the US accounts for about 7 per cent of Irish exports and 32 per cent of imports.

As with merchandise trade, a large share of the trade in services products is likely accounted for by intra-company trade, i.e., multinational companies operating in Ireland import services products to input into their production processes to produce exports of merchandise and services products for final consumption elsewhere. In particular, the pharmaceutical sector uses a large amount of services inputs in production.

\footnotetext{
${ }^{9}$ In broad terms, GDP measures the total output of the economy, whereas GNP measures output produced by residents of the country. It is well known that Irish GDP is significantly higher than GNP due to the large presence of foreign owned multinational companies operating in Ireland. The activities of these companies generate incomes that accrue to their owners. These incomes are greater than the incomes of Irish residents generated abroad and so net factor income reduces GNP below the GDP level. There is considerable debate on the appropriateness of using GDP or GNP for international comparisons of the Irish economy but GDP seems to the logical measure when examining corporate taxation.
} 


\section{Figure 5: Share of US Trade in Ireland's Imports and Exports}

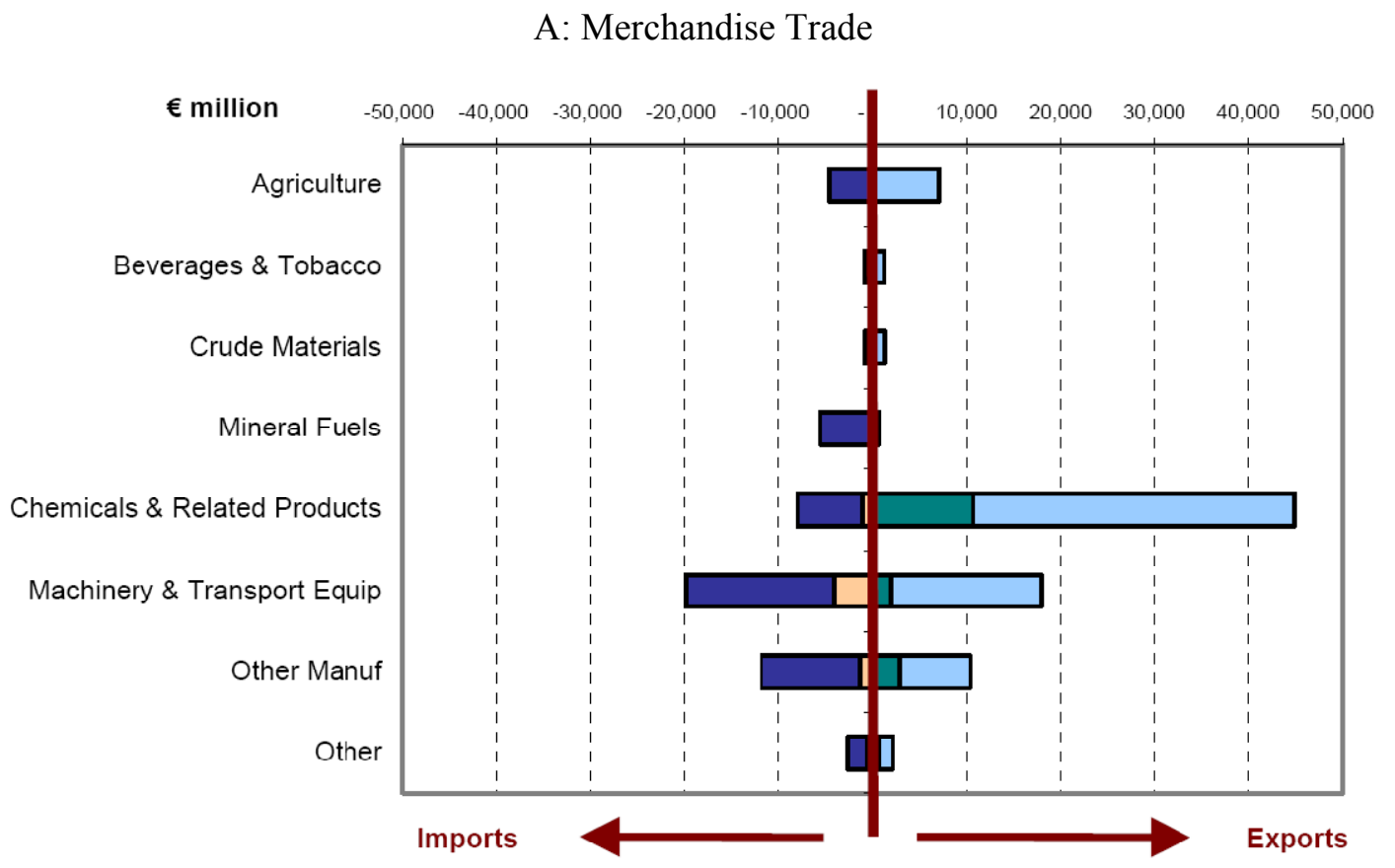

口Imports from US 口Imports from Rest of World aExports to US DExports to Rest of World

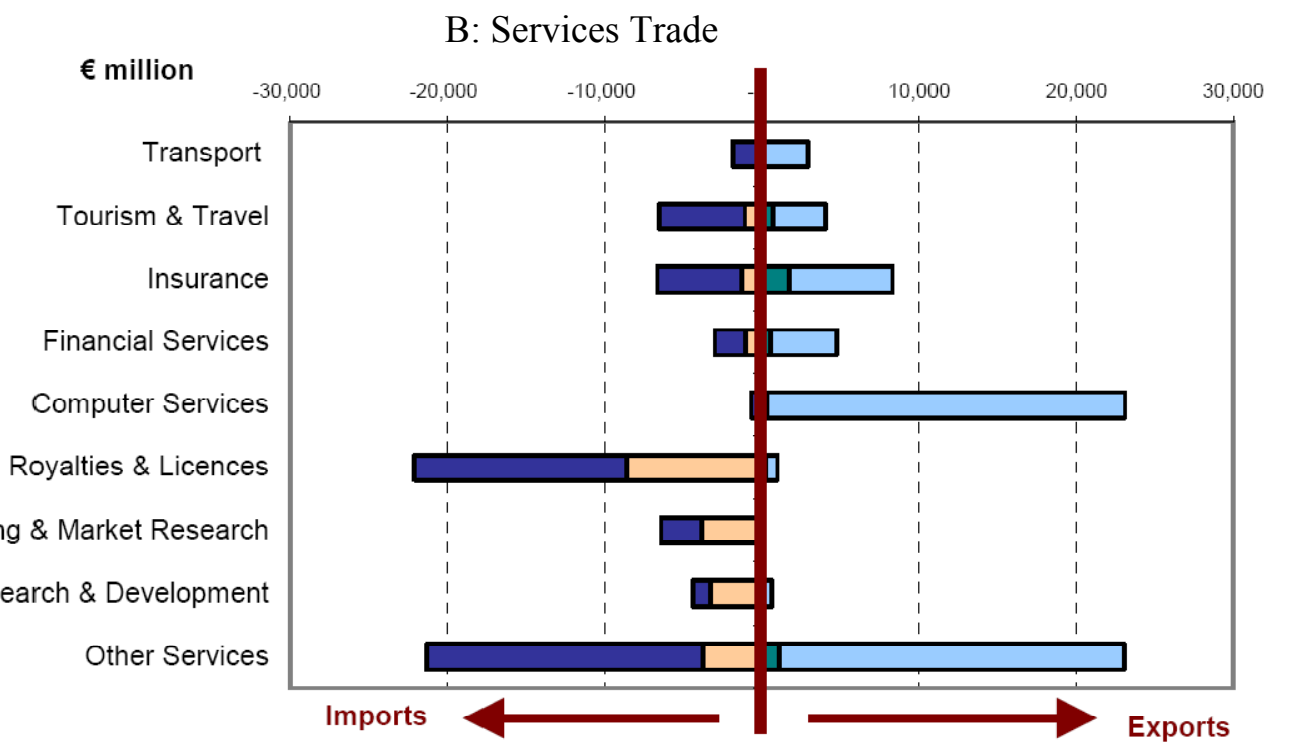

口Imports from US DImports from Rest of World DExports to US DExports to Rest of World

Source: CSO data and author's calculations. The data show the three year average for 2007 to 2009.

The largest import category, aside from the "other services" category, is royalties and licences services. However, there are almost no exports of royalties and licences services from Ireland. This category of services covers payments and receipts for the use of intellectual property (IP). An import of royalties and licences implies payment to a non-resident for the use of IP. From CSO data, the US accounts for nearly half of Irish imports of royalties and licences. Some US multinational companies, in particular in the pharmaceutical sector, have licensed their IP to Ireland for use by their affiliates. The high level of imports is the result of Irish-based companies making payments for the use of this IP. CSO data suggest that the ICT and research and development sectors are the main importers. ${ }^{10}$ In return, the Irish affiliates generate income and sales using the IP.

\footnotetext{
${ }^{10}$ From the CSO's Annual Services Inquiry 2006 but this refers to the payment for the use of royalties (domestic or imported) by all services companies in Ireland - Irish and foreign owned.
} 


\subsubsection{Employment by US Companies in Ireland}

Published data from the CSO on employment by US companies in Ireland are limited. On services, the CSO Annual Services Inquiry reports that US companies directly employed 33,000 people in Ireland in 2006 - around 7 per cent of total employment in services and 25 per cent of employment in services by foreign multinational companies.

The BEA provides a more detailed sectoral breakdown of employment by affiliates of US companies operating in Ireland shown in Table 3. The data indicate that US companies employed 91,000 people in Ireland on average between 2006 and 2008 - very close to the estimates reported by the IDA (2009) for supported companies of US origin (e.g., 94,000 employees in IDA companies in 2008). This represents about 5 per cent of total employment in Ireland (around 2 million at the time).

At a sectoral level, the largest employment shares are in manufacturing industries but the wholesale trade, professional services and information sectors also employ significant numbers. Employee compensation per head is highest in the chemicals, professional services and information sectors.

Table 3: Employment and Employee Compensation in US Companies in Ireland

\begin{tabular}{|c|c|c|c|}
\hline Scctor & $\begin{array}{c}\text { Employment } \\
(000 \mathrm{~s})\end{array}$ & $\begin{array}{l}\text { Compensation } \\
\text { of Employecs } \\
(€ \text { million })\end{array}$ & $\begin{array}{l}\text { Compensation } \\
\text { per Employee } \\
(€)\end{array}$ \\
\hline Fond & 1.8 & 99 & 53,359 \\
\hline Chemicals & 13.8 & 847 & 64,969 \\
\hline Computers \& electronic products & 18.8 & 924 & 45,484 \\
\hline Electrical equipment, appliances \& components & 1.0 & 41 & 45,129 \\
\hline Other manufacturing & 18.6 & 817 & 38,459 \\
\hline Wholesale trade & 6.7 & 313 & 45,644 \\
\hline Information & 5.6 & 322 & 57,315 \\
\hline Finance & 2.9 & 153 & 50,273 \\
\hline Professional services & 5.0 & 297 & 54,700 \\
\hline Other & 16.8 & 532 & 29,799 \\
\hline All Sectors & 91.2 & 4,355 & 45,634 \\
\hline
\end{tabular}

Source: BEA and author's calculations. The data show the three year average for 2006 to 2008 (data for 2008 are preliminary and may be revised).

\section{IDENTIFYING US COMPANIES AND PRELIMINARY ANALYSIS}

In their standard format Revenue's data do not distinguish companies based on the location of their headquarters or nationality of ownership of their parent company. Therefore, it is not possible to estimate directly the share of revenue from corporation tax (CT) or any other tax that is attributable to US multinational companies. The same applies to companies from any other country.

As a preliminary step using existing Revenue data, the share of CT revenue from large companies can be analysed. Revenue's Large Cases Division (LCD) handles the tax affairs of companies over a certain size threshold. These companies are a mix of Irish and foreign owned. LCD companies account for around 75 per cent of the total CT revenue in most years (on average over the period 2000 to 2009).

As a further preliminary assessment, an earlier exercise examined the top 250 companies in terms of CT payments (i.e., the 250 companies that made the largest payments in a particular year - the 2006 tax year was chosen). ${ }^{11}$ The total CT revenue for 2006 was $€ 6.2 \mathrm{bn}$ and the top 250 companies accounted for $€ 3.8 \mathrm{bn}$ of the total (shown in Table 4).

\footnotetext{
${ }^{11}$ Companies refer to individual companies rather than corporate groups. In several cases, corporate groups have multiple companies within the top 250 analysed here.
} 
Table 4: Corporation Tax Revenue from Top 250 Companies

\begin{tabular}{|c|c|c|c|}
\hline Country & $\begin{array}{c}\text { Corporation } \\
\text { Tax Revenue } \\
(€ \text { million })\end{array}$ & $\begin{array}{c}\text { Corporation } \\
\text { Tax Revenue } \\
(\%)\end{array}$ & $\begin{array}{l}\text { Number of } \\
\text { Companies }\end{array}$ \\
\hline Total CT Revenue for 2006 & 6,223 & - & - \\
\hline CT Revenue from Top 250 Companies & 3,766 & $100 \%$ & 250 \\
\hline \multicolumn{4}{|l|}{ of which country of ownership is: } \\
\hline Ireland & 762 & $20 \%$ & 63 \\
\hline US & 1,811 & $48 \%$ & 84 \\
\hline UK & 502 & $13 \%$ & 32 \\
\hline Other EU & 537 & $14 \%$ & 54 \\
\hline Rest of the World & 154 & $4 \%$ & 17 \\
\hline
\end{tabular}

Source: Revenue data and author's calculations. The data relate to the 2006 tax year.

Based on the location of their ownership or headquarters, these 250 companies were classified into Irish, US, UK, Other EU and Rest of the World. The largest number (84 companies) were US-owned. US companies paid $€ 1.8 \mathrm{bn}$ CT revenue (or 48 per cent of the CT revenue from the top 250). Irish owned companies paid the next largest share of CT revenue (20 per cent) followed by UK and rest of EU. The Rest of the World category, in which Canadian companies are the most represented, was relatively small.

To enable a more complete analysis than focusing on the top 250 companies as above, Revenue's LCD staff have compiled a list of all US-owned companies among the LCD case base. ${ }^{12}$ The list is manually assembled and as such there may be some errors or omissions. However, LCD staff are familiar with the cases in question and the completed list has been careful scrutinised and compared to external sources wherever possible. Therefore, the list is taken to be accurate and reliable and forms the basis for presenting a detailed analysis of the fiscal contribution of US companies in Ireland for the first time.

The list assembled by LCD provides an inventory of US companies in Ireland. These are further linked together by LCD to identify the companies (affiliates) that make up corporate groups.

Each company has a unique a tax number and can be linked to Revenue's register data (which identifies features such as location or economic activity) and to data on tax returns and tax payments made. For corporation tax, the primary tax return is the annual CT 1 return. The companies are also linked to VAT data (primarily the VAT 3 return and VAT payments data), employee and income tax data (based primarily on the P35 return) and excise duty payments. ${ }^{13}$ While all companies are registered for CT in Ireland, not all are registered for other taxes (such as VAT) depending on their structure and activities.

The analysis in the next section focuses the year for which most recent full year data are available. In most cases 2009 data are used for tax payments but in some cases tax returns data for 2009 are not available. This can be because of the due date for the return (e.g., the CT1 for a company with a tax year ending on 31st December 2009 was not due until September 2010, whereas the tax payment for the year ending 31st December 2009 is made during 2009) or the returns are made but the data are not yet available for analysis purposes due to the time needed to capture the data electronically.

\footnotetext{
${ }^{12}$ Some US companies may fall outside of LCD and reside in one of Revenue's regions and therefore are not counted in this analysis. However, it would expected that the number of companies involved is low and their tax payments are small.

${ }^{13}$ Further details on tax returns and the data captured in each can be found on www.revenue.ie.
} 


\section{FISCAL CONTRIBUTION OF US COMPANIES IN IRELAND}

\subsection{Corporation Tax Revenue from US Companies}

There are nearly 650 US companies in Ireland identified by LCD. ${ }^{14}$ Using this list, the CT payments by US companies are identified and the results are shown in Table 5.

Table 5: Corporation Tax Revenue from US Companies 2001 to 2009

\begin{tabular}{ccc}
\hline Year & $\begin{array}{c}\text { Corporation Tax Revenue } \\
\text { from US Companies } \\
\text { (€ million) }\end{array}$ & $\begin{array}{c}\text { Share of Total Corporation } \\
\text { Tax Revenue }\end{array}$ \\
\hline & 1,189 & $28 \%$ \\
\hline 2000 & 1,550 & $36 \%$ \\
\hline 2001 & 1,720 & $40 \%$ \\
\hline 2003 & 1,597 & $37 \%$ \\
\hline 2004 & 1,562 & $35 \%$ \\
\hline 2005 & 1,828 & $35 \%$ \\
\hline 2007 & 1,907 & $31 \%$ \\
\hline 2008 & 1,742 & $28 \%$ \\
\hline 2009 & 2,090 & $40 \%$ \\
\hline
\end{tabular}

Source: Revenue data and author's calculations.

The amount of CT revenue from US companies is substantial, €2bn at its peak in 2008 and over one third of total revenue from all companies in most years. It is notable that, although revenue from US companies decreased in 2009 due to the impact of the economic downturn, it appears revenue from US companies was less severely affected than the overall corporate tax base. US companies in Ireland depend serve customers internationally and global demand has suffered less than domestic Irish demand during the recession. In addition, as discussed below, US companies in Ireland are heavily concentrated in sectors that are to some extent "recession proof" (pharmaceuticals and medical devices for example). Overall CT revenue decreased 40 per cent between 2007 and 2009 but revenue from US companies only fell by only 4 per cent in the same period. The results from Table 5 are shown graphically in Figure 6.

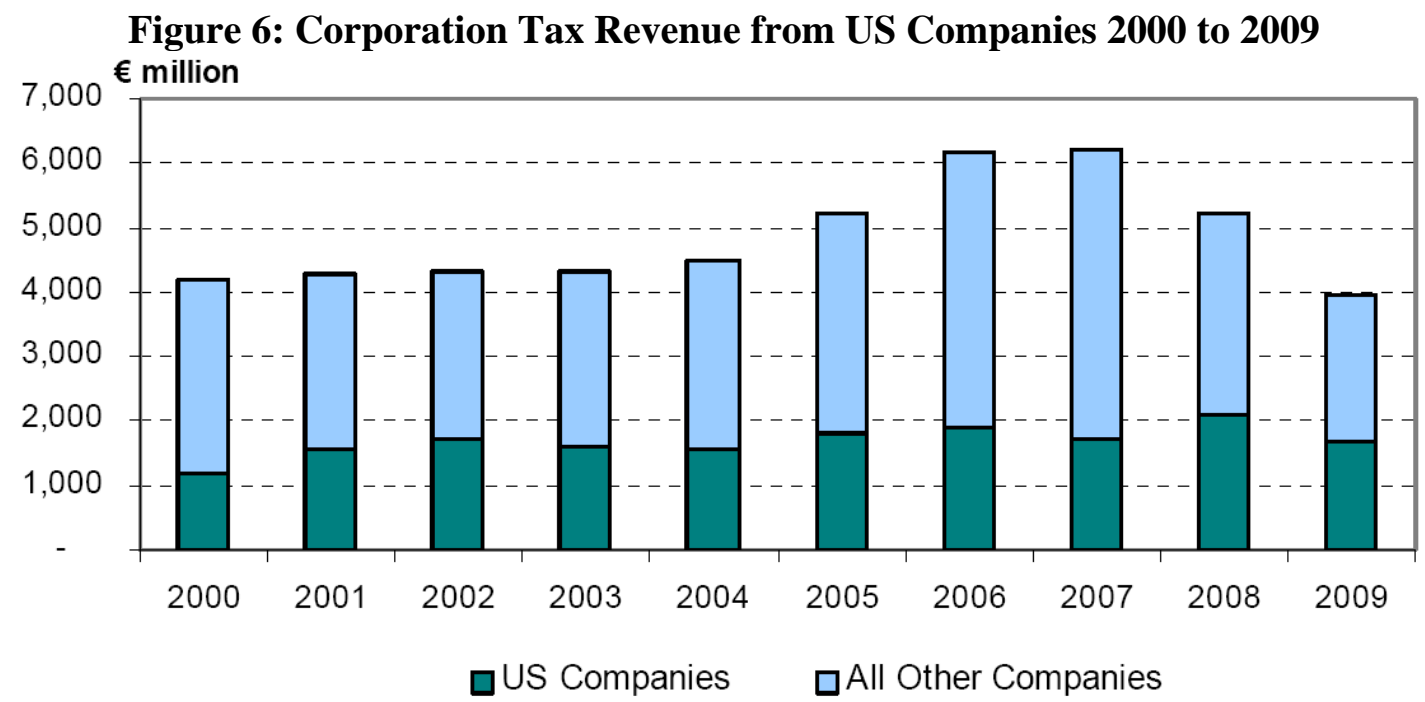

Source: Revenue data and author's calculations.

\footnotetext{
${ }^{14}$ As noted above, companies here refer to individual companies rather than corporate groups.
} 
For the US companies, Figure 7 shows the distribution of their CT revenue by sector. The financial services, chemical manufacturing and electrical equipment manufacturing are by far the largest. Looking at previous years' data, the size and relative importance of these sectors is quite stable over time.

The distribution of CT revenue from US companies by sector is quite similar to the overall distribution of CT. There are differences, for example construction and manufacturing of food products are important sectors for CT revenue overall but are underrepresented in among the US companies.

Figure 7: Corporation Tax Revenue from US Companies by Sector

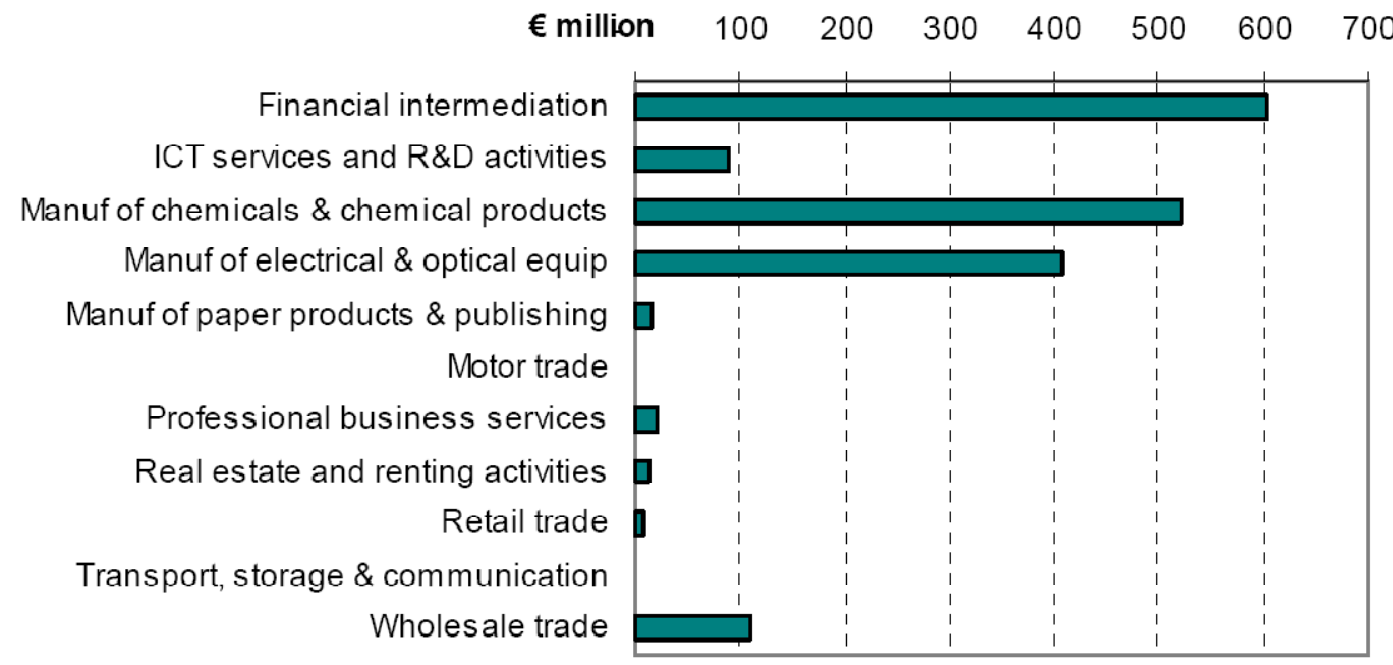

Source: Revenue data and author's calculations. Sectors with small numbers of companies are not shown to protect the confidentiality of the taxpayers. The data show the three year average (tax years 2007 to 2009).

The sectoral distribution (based on NACE code) in Figure 7 may be slightly misleading. Some of the US companies are affiliates of a corporate group that provide financial services and other financial intermediation services for the corporate group. The affiliates are classified as financial intermediation companies under the NACE system whereas their parent company and other companies within the group are classified as pharmaceutical, electrical equipment, or other as appropriate.

To provide more detail on the activities of US companies for the three largest sectors (financial intermediation, chemicals manufacture and electrical equipment manufacture), Table 6 shows the breakdown of CT revenue by their main subsectors. The subsectoral definitions (again based on NACE code) are not very useful for the financial intermediation sector but do offer better insights into the chemical and electrical equipment sectors.

US companies in the chemical sector are mostly involved in pharmaceutical and related products manufacture, while computer and information processing equipment is important in the electrical manufacturing sector, as is medical devices manufacturing. 
Table 6: Subsector Activities of US Companies

\begin{tabular}{|c|c|c|}
\hline Sector & Subsector & $\begin{array}{c}\text { Corporation } \\
\text { Tax Revenue } \\
(€ \text { million })\end{array}$ \\
\hline \multicolumn{3}{|c|}{ Financial Intermediation } \\
\hline & Total & 544 \\
\hline & Activitics auxiliary to financial intermediation n.c.c. & 3 \\
\hline & Activities auxiliary to insurance and pension funding & 2 \\
\hline & Financial leasing & 6 \\
\hline & Non-life insurance & 17 \\
\hline & Other credit granting & 237 \\
\hline & Other financial intermediation n.e.c. & 173 \\
\hline & Other monetary intermediation & 79 \\
\hline & Security broking and fund management & 5 \\
\hline \multicolumn{3}{|c|}{ Manufacture of chemicals and chemical products } \\
\hline & Total & 571 \\
\hline & Manufacture of basic pharmaceutical products & $22 \hat{3}$ \\
\hline & Manufacture of other organic basic chemicals & 103 \\
\hline & Manufacture of pharmaceutical preparations & 223 \\
\hline \multicolumn{3}{|c|}{ Mamufacture of electrical and optical equipment } \\
\hline & Total & 320 \\
\hline & $\begin{array}{l}\text { Manufacture of computers and other information } \\
\text { processing equipment }\end{array}$ & 114 \\
\hline & $\begin{array}{l}\text { Manufacture of electronic valves and tubes and other } \\
\text { electronic components }\end{array}$ & 61 \\
\hline & $\begin{array}{l}\text { Manufacture of medical and surgical equipment and } \\
\text { orthopaedic appliances }\end{array}$ & 100 \\
\hline
\end{tabular}

Source: Revenue data and author's calculations. The data relate to tax year 2009. Subsectors with small numbers of companies are not shown to protect the confidentiality of the taxpayers.

Figure 8 shows the distribution of CT revenue by location to illustrate the spread of US companies across Ireland. The location is based on the bailiwick the company. ${ }^{15}$ Over half of CT revenue from US companies is located in Dublin (City and County), there are also large shares located in Cork County and Limerick.

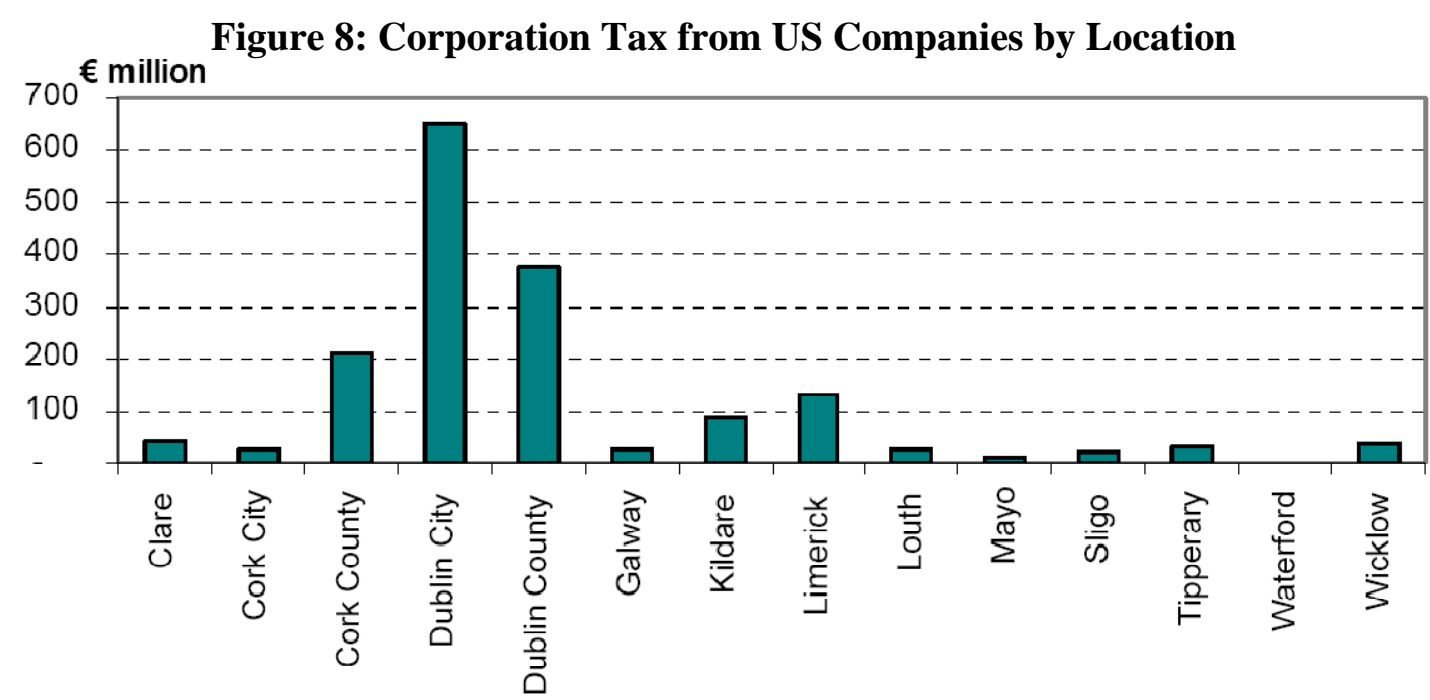

Source: Revenue data and author's calculations. The data show the three year average for tax years 2007 to 2009 . Bailiwicks with small numbers of companies are not shown to protect taxpayer confidentiality.

\footnotetext{
${ }^{15}$ Bailiwick refers to a location over which a bailiff has jurisdiction. Bailiwicks are largely based on county areas but there are some differences. Dublin and Cork city are also separated from their respective counties.
} 


\subsection{Contribution of US Companies to Value Added Tax Revenue}

To further analyse US companies, the CT data are linked to VAT data. ${ }^{16}$ Later sections analyse the payments of US companies of excise duty and income tax to identify the contribution of the companies to these taxes.

US companies paid $€ 891 \mathrm{~m}, € 975 \mathrm{~m}$ and $€ 790 \mathrm{~m}$ in VAT revenue in 2007, 2008 and 2009 respectively. For example, this represents about 7.5 per cent of the total VAT revenue paid in 2009. Although it is still a significant amount of revenue, it is low compared to the share of CT from US companies. A partial explanation relates to the export oriented nature of US investment in Ireland. Many US companies operate in Ireland to supply markets in Europe or beyond. As a result, they will generate less VAT revenue than multinational companies that operate in Ireland primarily to supply the Irish market.

Figure 9 shows the sectoral distribution of the VAT revenue from US companies. The motor trade sector is the single largest contributor, there are two main subsectors in this sector: retail sale of automotive fuel and the sale of motor vehicles. Although not shown in Figure 9 due the small number of companies, the manufacture of refined fuel products sector also pays a large amount of VAT. These are sectors in which US companies are operating in Ireland predominately to supply the Irish market (as opposed export supply to markets in Europe or elsewhere). Other significant sectors are electrical manufacturing (computer and related products and medical and surgical devices) and wholesale trade (predominantly sales of food and beverages, computers and related products and pharmaceuticals).

\section{Figure 9: VAT Revenue from US Companies by Sector}

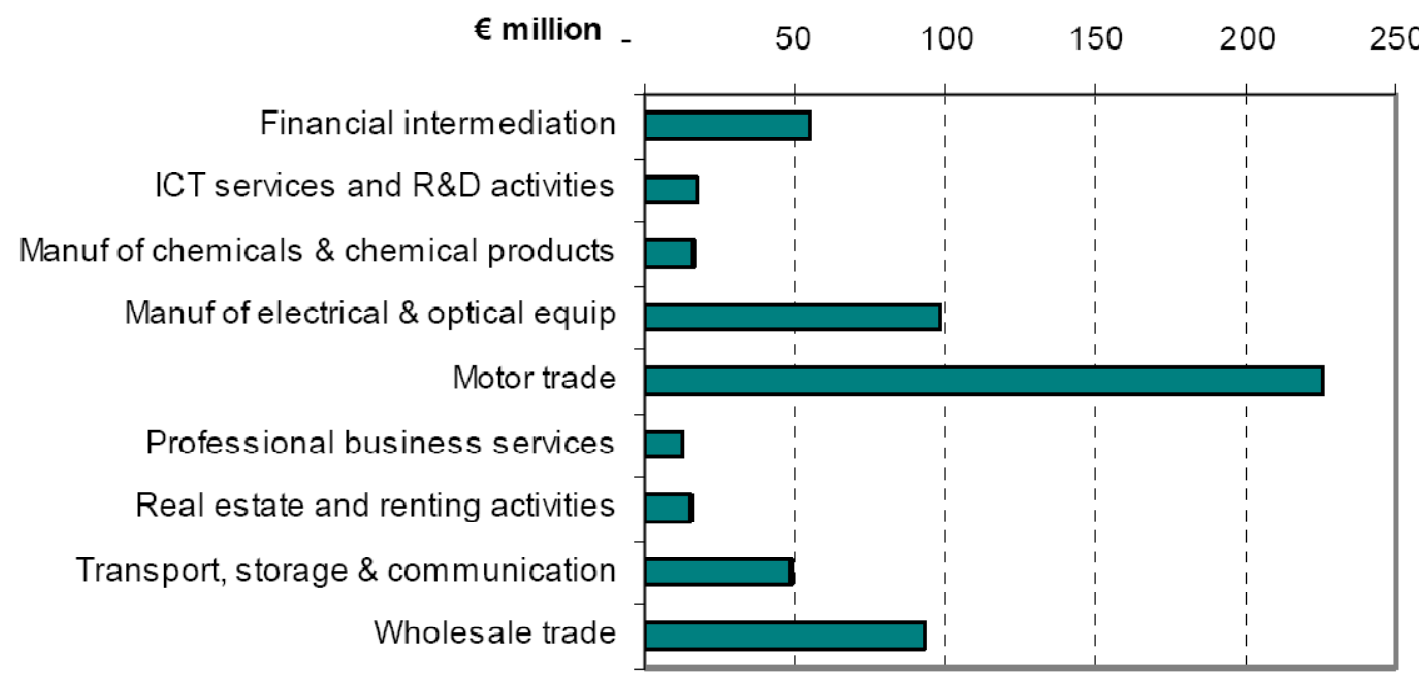

Source: Revenue data and author's calculations. Sectors with small numbers of companies are not shown to protect the confidentiality of the taxpayers. The data relate to the 2009 tax year.

\subsection{Contribution of US Companies to Excise Duty Revenue}

The number of US companies that pay excise duty is very small but the amount of revenue involved is high. Around ten US companies paid excise duty in 2009 but their combined payment was $€ 986 \mathrm{~m}$, which is equal to 20 per cent of the total excise duty paid in that year. US companies paid $€ 900 \mathrm{~m}$ in excise duty in 2008 .

The excise revenue paid by these ten companies was concentrated among a very small number of companies. These companies are operating in the retail sale of automotive fuel and manufacture of refined petroleum products sectors. It is worth noting that the same ten companies that paid $€ 986 \mathrm{~m}$ in excise duty also paid $€ 403 \mathrm{~m}$ in VAT in 2009 (out of the $€ 790 \mathrm{~m}$ cited in Section 4.2).

\footnotetext{
${ }^{16}$ VAT revenue here refers to VAT internal and does not include VAT paid on imports.
} 


\subsection{Contribution of US Companies to Income Tax Revenue and Employment}

Based on Revenue data, US companies employed around 100,100 people in Ireland in 2008. This represents about 5 per cent of 2 million in employment in that year. The income tax revenue from these employees for that year was $€ 698 \mathrm{~m}$ or 7 per cent of the total income tax revenue of $€ 10 \mathrm{bn}$ from pay-as-you-earn (PAYE) sources. Employment by US companies in 2007 was slightly higher, at 108,200 and PAYE revenue was $€ 650 \mathrm{~m}$.

Figure 10 shows the sectoral distribution of employees and income tax revenue from US companies. Tax revenue and employee numbers are closely related as would be expected. The largest sectors are electrical manufacturing, chemical manufacturing and financial intermediation (the same caveat regarding the NACE code assigned to financial services companies as noted earlier applies here also). Wholesale trade, professional business services and ICT services and R\&D activities sectors are also important.

\section{Figure 10: Income Tax Revenue and Number of Employee of US Companies}

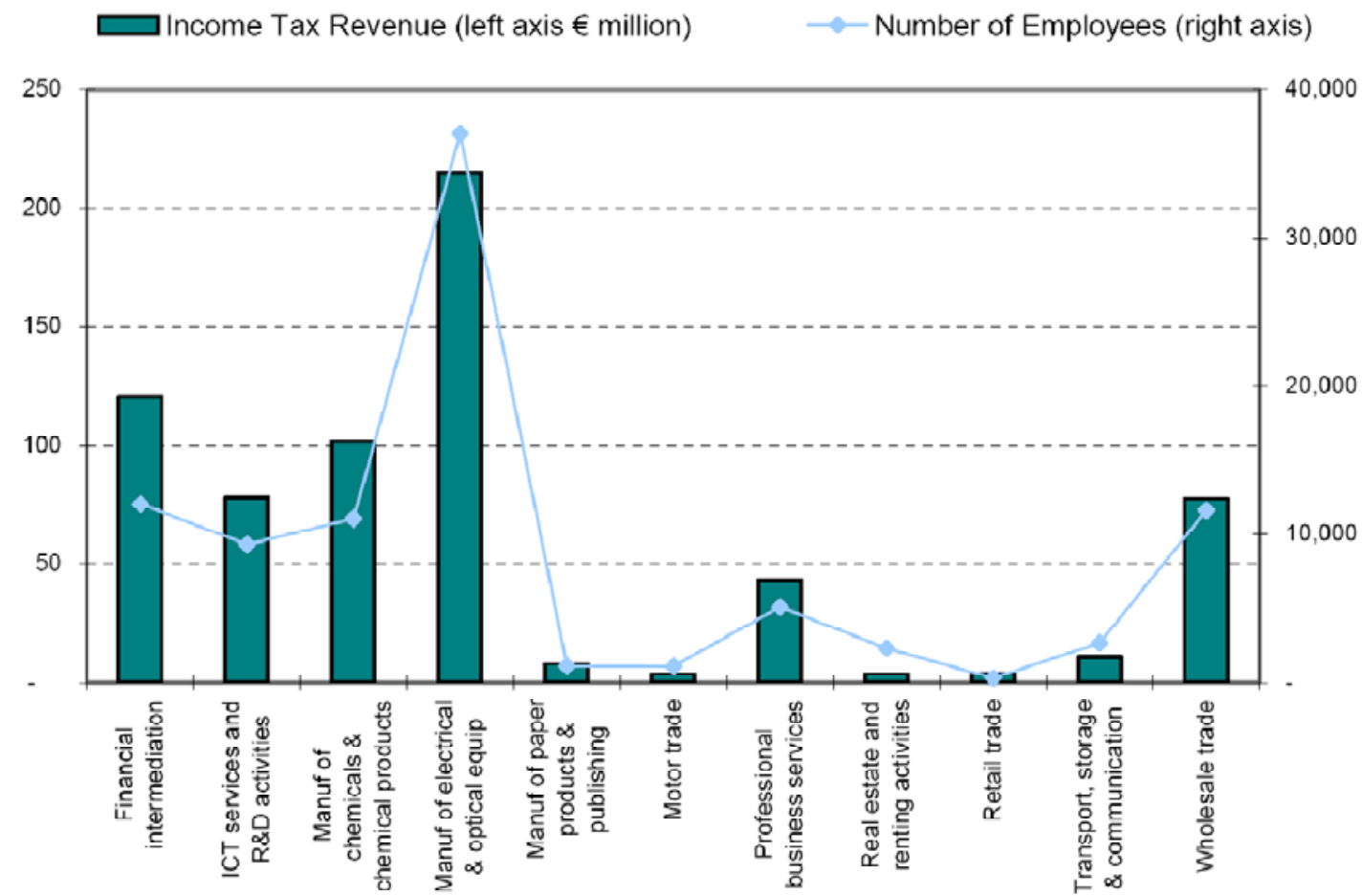

Source: Revenue data and author's calculations. Sectors with small numbers of companies are not shown to protect the confidentiality of the taxpayers. The data relate to the 2008 tax year.

Figure 11 analyses the sectoral composition of employment by US companies for three years (2002, 2006 and 2008). The total number of employees of US companies increased from 74,300 in 2002 to 106,800 in 2006 and then reduced to 100,600 in 2008. Figure 11A shows the share of employment (rather than the number of employees) by US companies by sector. For example, in 2002 the financial intermediation sector had 7 per cent of employees of US companies in Ireland but by 2006 this sector employed 10 per cent of the workforce of US companies and the share increased to 12 per cent by 2008. By focusing on the share rather than the change in number of employees, the relative changes across sectors can be assessed.

Broadly speaking, the manufacturing sectors have seen their share of employee numbers decreasing, while there are increases in services: financial intermediation, ICT services and R\&D activities and wholesale trade. Professional business services saw a strong increase between 2002 and 2006 but the employment level fell between 2006 and 2008.

Figure 11B shows the change in the average (median) annual income per employee of US companies by sector. There are difficulties in calculating median incomes as the figures include part-time employees and those that may have worked for less than a full year. For example, this appears to be a particular issue in the real estate and renting sector, which shows very low median incomes. Therefore the average figures may not accurately reflect employee compensation in the companies but the trends in the changes over time are still interesting to examine. 
Figure 11B shows that average income increased in most sectors, as would be expected, but the rate of increase was fastest in the manufacturing sectors. The increase in average compensation for most sectors over the period 2006 to 2008 was greater than the increase from 2002 to 2006. Average employee income grew by 12 per cent over the period 2002 to 2006 but rose by 24 per cent between 2006 and 2008. In the period 2006 to 2008, overall employment in US companies declined. It suggests that most of the decrease in employment probably occurred due to the reduction in lower paid positions.

Figure 11: Employment and Employee Compensation in US Companies

A: Share of US Company Employment by Sector

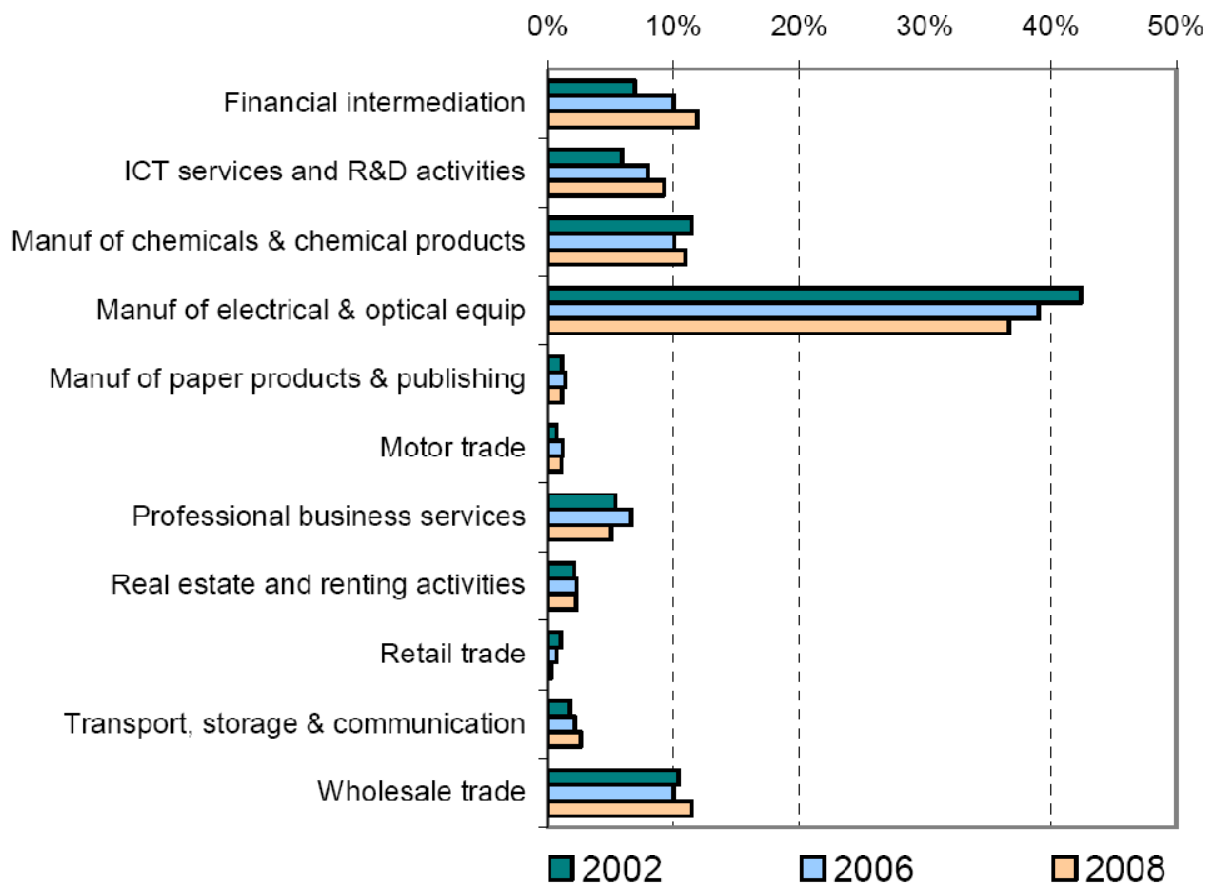

B: Average Employee Compensation in US Companies

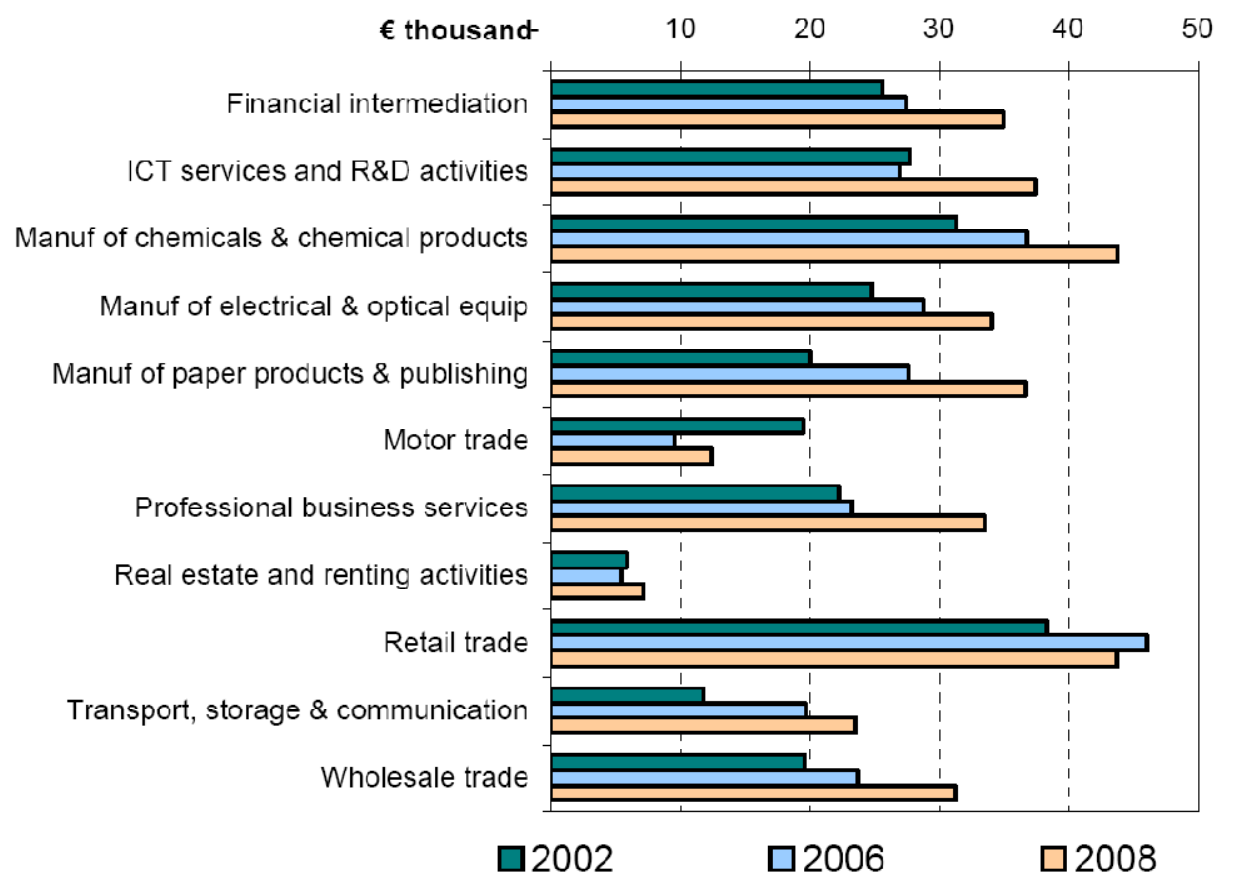

Source: Revenue data and author's calculations. Sectors with small numbers of companies are not shown to protect the confidentiality of taxpayers. 


\subsection{Comparisons to Other Data Sources}

Aside from the Revenue data discussed in the previous sections, there are several other data sources that estimate the level of CT paid by US multinational companies. Estimates from different sources from 2000 onwards, where available, are summarised and compared in Table 7. Aside from the Revenue data, only the BEA produces annual figures and the comparisons below focus on these two sources.

The BEA (Bureau of Economic Analysis) is an agency of the US Department of Commerce that provides economic statistics on a range of domestic and international topics. International investment data on US companies are primarily based on surveys and extrapolation of survey results. ${ }^{17}$

Table 7: Summary of Sources for Corporation Tax Revenue from US Companies

\begin{tabular}{|c|c|c|c|c|}
\hline Year & $\begin{array}{l}\text { Revenue } \\
\text { (€ million) }\end{array}$ & $\begin{array}{c}\text { BEA } \\
(€ \text { million })\end{array}$ & $\begin{array}{c}\text { IRS } \\
\text { (€ million) }\end{array}$ & $\begin{array}{c}\text { Forfas } \\
\text { (€ million) }\end{array}$ \\
\hline 2000 & 1,189 & 1,458 & & \\
\hline 2001 & 1,550 & 1,409 & & \\
\hline 2002 & 1,720 & 2,194 & & \\
\hline 2003 & 1,597 & 1,785 & & \\
\hline 2004 & 1,562 & 1,543 & 1,287 & \\
\hline 2005 & 1,828 & 2,133 & & \\
\hline 2006 & 1,907 & 1,997 & 1,436 & 2,100 \\
\hline 2007 & 1,742 & 2,565 & & \\
\hline 2008 & 2,090 & 2,312 & & \\
\hline 2009 & 1,677 & & & \\
\hline
\end{tabular}

Source: Institutions cited above and own calculations. BEA data for 2008 are preliminary and may be revised.

Overall, the BEA estimates in Table 7 appear to be quite close to the results from the Revenue data. However, there are differences in some years, for example BEA estimate the tax paid by US multinational companies in Ireland in 2007 was $€ 2.6 \mathrm{bn}$, considerably higher than the Revenue estimate $(€ 1.7 \mathrm{bn})$. The sectoral breakdown of the BEA data is shown in Table 8 . Figure 7 shows the same breakdown for the Revenue data.

Table 8: Tax Paid by US Companies in Ireland - BEA Estimate

\begin{tabular}{lcc}
\hline \multicolumn{1}{c}{ Sector } & $\begin{array}{c}\text { Tax Paid } \\
(€ \text { million })\end{array}$ & $\%$ \\
\hline Food & 17 & $1 \%$ \\
\hline Chemicals & 419 & $18 \%$ \\
\hline Computers \& electronic products & 220 & $10 \%$ \\
\hline Electrical equipment, appliances \& components & 5 & $0 \%$ \\
\hline Other manufacturing & 187 & $8 \%$ \\
\hline Wholesale trade & 570 & $25 \%$ \\
\hline Information & 268 & $12 \%$ \\
\hline Finance & 160 & $7 \%$ \\
\hline Professional services & 23 & $1 \%$ \\
\hline Other & 422 & $18 \%$ \\
\hline All Sectors & 2,291 & $100 \%$ \\
\hline
\end{tabular}

Source: BEA data and author's calculations. Figures are the three-year average (2006 to 2008). The data related to 2008 are preliminary and may be revised.

\footnotetext{
${ }^{17}$ Some banking activities are excluded from the detailed BEA data. However, these appear to be small in size. For example, according to BEA data for 2008, the sales of all companies in Ireland amounted to US\$255bn but sales of the non-bank companies amounted to US\$250bn. Any BEA data discussed in this paper refer to non-bank companies unless otherwise specified.
} 


\subsection{Effective Tax Rates for US Companies in Ireland}

There has been increased comment recently on the perception that multinational companies from the US (and other countries) are abusing transfer pricing rules to shift excessive profits into their Irish affiliates to take advantage of Ireland's low corporation tax rate. Some commentators have been influenced by the use of BEA data to calculate effective tax rates (ETR) for US companies located in Ireland. The results appear to show low ETR, well below the 12.5 per cent rate. For example, the BEA data indicate US companies in Ireland paid CT revenue of $€ 2.3 \mathrm{bn}$ in 2007 and reported combined profits of $€ 33.3 \mathrm{bn}$. This implies an aggregate ETR of 7.7 per cent for 2007.

On the tax paid, Revenue data suggest US companies paid $€ 1.7 \mathrm{bn}$ in 2007 , not $€ 2.3 \mathrm{bn}$ as reported in the BEA data. However, the BEA profit figure for US companies in Ireland is also misleading. The BEA data appear to include companies that are registered in Ireland but are non-resident for tax purposes. The BEA data classify profits of non-resident companies as being located in Ireland, whereas in reality the profits are earned and are taxable elsewhere (wherever the company is tax resident).

This has the effect of the inflating the profit before tax estimate of Irish-based US companies in the BEA data. When compared to the level tax paid in Ireland by US companies reported by the BEA, this produces a low ETR as noted above.

Using the LCD list of US companies, it is possible to match their CT payments to the CT1 return and compare the profits earned to the tax paid and calculate a rough ETR. ${ }^{18}$

The ETR is estimated at the level of the individual companies, unlike the estimates based on aggregate BEA data. The average (median) ETR for US companies for 2008 was 11.2 per cent. In 2007 the median ETR was 11.1 per cent. The median ETR in 2009 was 9.5 per cent but this figure is preliminary pending the full set of tax return data for 2009 .

The ETR would not be expected to match the standard 12.5 per cent rate exactly due to variations in the taxable base and, in particular, some manufacturing profits are taxable at 10 per cent in Ireland (this rate is important for many US companies). ${ }^{19}$ But it is striking that the average for US companies is very close to the standard rate and well above estimates produced with aggregated BEA data.

As noted in the discussion of the figures in Table 8, the estimates for tax paid in Ireland by US companies from Revenue and BEA are similar (but not identical). However, the BEA data inflate the profit levels of US companies in Ireland due to the inclusion of data on non-resident companies and distorts the ETR calculation. ${ }^{20}$

\section{CONCLUSION}

Investment in Ireland by US-owned multinational companies has been substantial over recent decades. However, it is difficult to accurately measure the size of the contribution of US companies to the Irish economy. This paper uses Revenue data for the first time to assess the corporation tax, VAT, excise duty, income tax and employment contribution of US companies in Ireland.

The list of US companies assembled by Revenue's Large Cases Divisions has been carefully scrutinised and compared to external sources. The list is as accurate and reliable as possible. If any omissions exist, or where issues arise in linking data across Revenue sources, it is likely that the estimates presented in this paper slightly underestimate the contribution of US companies to tax revenue and employment in Ireland.

US companies in Ireland paid $€ 1.7 \mathrm{bn}$ CT revenue in 2009. In most years of the last decade, US companies have consistently contributed over one third of CT revenue in Ireland. The VAT revenue

\footnotetext{
${ }^{18}$ More precisely, the ETR is calculated as the ratio of the net payment of CT over the sum of the "Trade Profits chargeable at the Standard Rate of $12.5 \%$ " and "Trade Profits chargeable at the Manufacturing rate of 10\%". As noted, this is a rough estimate of the ETR. It may not capture all profits of companies. Capital allowances and other reliefs and credits are deducted from trade profits and these deductions lower the ETR below the statutory 12.5 per cent rate.

${ }^{19}$ The 10 per cent manufacturing rate will end for all companies by end 2010 .

${ }^{20}$ Barry and Bergin (2010) provides an excellent summary of other aspects of the interaction between the US and Irish corporate tax systems.
} 
and excise duty from these companies were $€ 790 \mathrm{~m}$ and $€ 986 \mathrm{~m}$ respectively for 2009. US companies employ over 100,000 people in Ireland, with €698m income tax revenue paid in 2008.

Across CT, VAT and income tax, the most significant sectors were financial intermediation services, manufacture of pharmaceuticals, manufacture of computer and related products, manufacture of medical devices and wholesale trade in the sale of these manufactured products. The sectoral mix of excise duty is somewhat different due to the nature of the products involved. Examining changes over time shows a movement in activities of US companies in Ireland away from manufacturing towards more service oriented sectors. Employee compensation levels rose considerably over the last decade. The recession appears to have resulted in jobs losses among lower paid employees.

The appendix contains a summary table of the fiscal contribution of US multinationals in Ireland for a single year (2008 in this case). The total revenue from these companies, across all taxes examined was $€ 4.7 \mathrm{bn}$ in the year. Total tax revenue in Ireland in 2008 was $€ 41 \mathrm{bn}$.

Final figures for the income tax contribution of US companies in 2009 are not available but all indicators for this, and for other taxes, suggest that the revenue paid by US companies has remained stable during the recession and that global demand served by US companies continues to perform better than domestic Irish demand. Therefore, as tax revenue overall falls, the share from US companies has been rising and their importance to the Irish exchequer continues to grow in relative terms.

On a final note, all of the analysis in this paper focuses on the direct effects of US investment. In addition, there are substantial indirect effects that are not captured in the available data. A simple example is the money spent locally by employees of US companies. Another is the output and employment of local companies that service or supply local operations of US companies. Skills transfers and research and development spending may also have positive spillovers to the domestic economy. Some estimates suggests that every job created by FDI sustains two to three more jobs indirectly. Such linkages are likely to be important to the Irish economy but unfortunately there are no recent estimates for the size of these effects in Ireland.

\section{References}

American Chamber of Commerce Ireland (2010), Factfile.

Barry, F. and Bergin, A., 2010, Ireland's Inward FDI over the Recession and Beyond, IIIS Discussion Paper No. 321.

Barry, F. and O'Mahony, C., 2004, Making Sense of the Data on Ireland's Inward FDI, Journal of the Statistical and Social Inquiry Society of Ireland, Vol. XXXIV.

Forfás, 2010, Annual Competitiveness Report 2010 - Volume 1: Benchmarking Ireland's Performance, National Competitiveness Council report published by Forfas.

Forfás, 2009, Annual Business Survey of Economic Impact 2008, report published by Forfas.

IBM, 2010, Global Location Trends - Annual Report, published by IBM Global Business Services.

Industrial Development Agency (IDA), various years, Annual Report.

Lane, P. and Ruane, F., 2006, Globalisation and the Irish Economy, Institute for International Integration Studies, Occasional Paper, No. 1.

Organisation for Economic Cooperation and Development (OECD), 2002, Economic Outlook 71.

\section{Data sources (all data sources were accessed in November 2010):}

Bureau of Economic Analysis (BEA) International Investment Position and Operations of Multinational Companies (www.bea.gov). 
Central Statistics Office (CSO): various data sets and publications (www.cso.ie).

Forfás: data from the Annual Business Survey of Economic Impact and the Annual Employment Survey are used (various years). Some additional data were received via correspondence with Forfas (www.forfas.ie).

Internal Revenue Service: IRS Statistics of Income on Controlled Foreign Corporations (http://www.irs.gov/taxstats/article/0,,id=117514,00.html).

International Monetary Fund (IMF): Portfolio Investment: CPIS Data

(http://www.imf.org/external/np/sta/pi/cpis.htm). 


\section{APPENDIX}

Summary of Fiscal Contribution by US Companies

\begin{tabular}{|c|c|c|c|c|c|c|}
\hline Sector & $\begin{array}{c}\text { Corporation Tax } \\
(\mathbf{E})\end{array}$ & $\begin{array}{l}\text { VAT } \\
(€)\end{array}$ & $\begin{array}{c}\text { Excise Duty } \\
(€)\end{array}$ & $\begin{array}{c}\text { Income Tax } \\
(\boldsymbol{E})\end{array}$ & $\begin{array}{c}\text { Employees } \\
\text { (number) }\end{array}$ & $\begin{array}{c}\text { Companies } \\
\text { (number) }\end{array}$ \\
\hline Financial intermediation & $850,305,383$ & $35,513,150$ & & $120,530,087$ & 12,034 & 191 \\
\hline $\begin{array}{l}\text { Manuf of chemicals \& } \\
\text { chemical products }\end{array}$ & $511,096,672$ & $15,626,969$ & & $101,668,272$ & 11,044 & 38 \\
\hline $\begin{array}{l}\text { Manuf of electrical \& } \\
\text { optical equip }\end{array}$ & $380,513,192$ & $122,586,187$ & & $214,982,519$ & 36,999 & 63 \\
\hline Other manufacturing & $42,133,807$ & $258,119,477$ & $430,328,433$ & $28,784,189$ & 1,973 & 14 \\
\hline Motor trade & 496,686 & $289,224,772$ & $461,892,624$ & $3,445,922$ & 1,104 & 5 \\
\hline $\begin{array}{l}\text { Professional business } \\
\text { services }\end{array}$ & $23,735,085$ & $18,774,109$ & & $43,167,287$ & 5,084 & 67 \\
\hline Wholesale trade & $125,654,416$ & $104,119,500$ & & $77,767,821$ & 11,604 & 51 \\
\hline Other sectors & $3,575,056$ & $2,549,727$ & & $3,840,566$ & 4,564 & 10 \\
\hline Total & $2,089,596,496$ & $975,300,506$ & $899,380,726$ & $698,054,041$ & 100,095 & 570 \\
\hline
\end{tabular}

Source: Revenue data and author's calculations. Sectors with a small number of companies are not shown to protect the confidentiality of taxpayers. The data relate to the 2008 tax year. 


\section{FIRST VOTE OF THANKS PROPOSED BY JIM STEWART, TRINITY COLLEGE DUBLIN}

This is a very interesting and topical paper. Corporate tax rates, and the role of corporate tax in industrial policy are viewed as central to economic policy and have led to considerable criticism from other countries (Stewart, 2011). This paper deals with some of these issues and in addition has some previously unpublished data, on corporate tax, VAT and other tax payments by US companies in Ireland.

The paper focuses on direct investment by US firms, and in particular on US companies identified from the Large Cases Division of the Revenue. As the paper notes the size in terms of value of foreign investment in Ireland is dominated by IFSC entities, but most employment is in direct investment. But rather than IFSC companies 'having little impact on the domestic economy' as the paper states, they may have a considerable economic impact. For example, a certain portion of ECB lending to banks in Ireland consists of lending to IFSC banks. IFSC based entities, such as Depfa bank, raise considerable regulatory issues. A breakdown in the paper of US direct investment between IFSC and non-IFSC investment in some sectors such as professional and technical services, data processing would be useful in understanding the impact of IFSC activities.

The paper notes the importance of multinational companies on Irelands imports and exports, and also the likely role of intra-company trade. This is important because intra firm trade to the extent that it reflects a chain of production and distribution, will be less influenced by exchange rates and other economic variables than other arms length trade. This is often not recognised in discussion of changes in imports or exports.

Table $5 \mathrm{~B}$ and the discussion of royalty payments is especially interesting. It is not well known that royalties on income from patents were tax exempt. This gave an incentive to develop or enhance patents transferred to Ireland. It was announced in the National Recovery Plan (2010: 96) that this relief would be abolished, although other important tax reliefs on intellectual property have been introduced in recent years. Flows relating to royalties and licenses are confusing in balance of payments statistics. For several years there has been a large outflow. But the logic of tax minimisation is that transfer of intellectual property (IP), for example from the U.S. to an Irish based subsidiary, should be done at minimal cost in terms of transfer of ownership or in terms of licence fees, as explained by Drucker (2010) in relation to Google. ${ }^{56}$ It might have been expected that if an IP asset were transferred to Ireland, this would lead to an inflow of royalty income, but in the case of Google and as noted in the paper, this transfer results in sales income, not royalty income. The large inflows from 'other services' in Table 5B are largely explained by companies pursuing such a strategy. There is a large outflow of royalty income and as the paper notes some of this is to the US, but in the case of some companies it is to a tax haven such as Bermuda. ${ }^{57}$ The flow of royalties is not to where the IP originated but to another country, with a tax rate lower than that in Ireland.

The analysis of Income Tax revenue and number of employees (Figure 11) raises some interesting questions. For example, what are the trends in wage rates through time and in comparison with other sectors and ownership categories? There are some surprises. Figure 11B shows that average (median) annual income is higher in retailing than in financial intermediation for US owned firms.

More controversially the paper shows some estimates of effective tax rates (ETR) for US companies based on revenue data and US Bureau of Economic Analysis (BEA) data. The paper criticises the low effective tax rate as calculated from BEA data of $7.7 \%$. Estimates given in the paper are of an average (median) ETR of $11.2 \%$. An ETR relatively close to the nominal tax rate of $12.5 \%$ is surprising, although the dispersion around the median is not given in the paper. There is often a large gap between nominal tax rates and effective tax rates, for example 700 companies in the Large Business Service unit of the UK revenue authorities (HMRC), 28\% paid no corporation tax in 2006-06 (National Audit Office, 2007: 10). As the paper notes there may be some ambiguity in relation to the residency for tax purposes of some companies in US data. In addition the allocation of branch profits may lead to inaccuracies. Effective tax rates are also likely to vary across sectors. For sectors with non-trading investment income the corporation tax rate if $25 \%$. This may be important for firms located in the IFSC.

\footnotetext{
${ }^{56}$ Drucker (2010) states:- "Income shifting commonly begins when companies like Google sell or license the foreign rights to intellectual property developed in the U.S. to a subsidiary in a low-tax country. That means foreign profits based on the technology get attributed to the offshore unit, not the parent. Under U.S. tax rules, subsidiaries must pay "arm's length" prices for the rights -- or the amount an unrelated company would".

${ }^{57}$ This arrangement is facilitated by Corporation Tax Statement of Practice SP - Ct/01/10, Treatment of Certain Parent Royalties Paid to Companies Resident Outside the State. Revenue Commissioners, Dublin.
} 
However, the two measures are not comparable. This is partly because of differences in companies assigned to Ireland in Irish Revenue data and BEA data. There are other differences. The BEA data refers to average tax rates (sum of corporate taxes paid divided by corporate income), whereas this paper refers to median tax rates. Relatively low aggregate average tax rates ETR could be explained by the dominance of a few companies earning large profits, but paying low tax. There are other differences, for example excluding income from equity investments in BEA data increases effective tax rates substantially (Yorgason, 2009).

This raises a key issue and that is the definition of the tax base. It is well known for example that income based on US GAAP may differ from that based on Irish/UK GAAP.

There are several examples from accounts of US subsidiaries in Ireland, of effective tax rates, defined as cash tax paid divided by pre-tax profits, similar to that found from BEA data and in some cases far below nominal tax rates (see Table 1 below). This is the case for some Irish companies as well. For example on a cash flow basis Ryanair paid tax of $7 \%$ on profits before tax for the three years ending March 2009, and Grafton Group paid 4.2\%, for the three years ending December 2009.

Table 1 Effective Tax Rate for Selected MNC’s Operating in Ireland for varying years

\section{\$ million}

\begin{tabular}{|c|c|c|c|c|}
\hline & $\begin{array}{c}\text { Boston } \\
\text { Scientific }^{1} \\
(2001-03)\end{array}$ & $\begin{array}{c}\text { Forest } \\
\text { Laboratories } \\
(2005-07)\end{array}$ & $\begin{array}{c}\text { Jansen } \\
\text { Pharmaceutial } \\
(2003-05)\end{array}$ & $\begin{array}{c}\text { Symantic } \\
(2004-5)^{3}\end{array}$ \\
\hline Turnover & 1243 & 4,755 & 12,430 & 275.1 \\
\hline Pre-tax Profit & 769 & $1,618.1$ & 4,195 & 101.7 \\
\hline Tax & 4.15 & 100.9 & 346.2 & 0 \\
\hline Effective tax rate \% & 0.52 & 6.2 & 8.2 & 0 \\
\hline
\end{tabular}

1 The accounts state the "The principal activity of this subsidiary is the holding of shares in other companies and related intellectual property for which it receives royalties"”.

2 In this case as a cash flow statement was not included in the accounts, the tax charge in the profit and loss account was used instead.

3 The principal activity is described as "investment and intellectual property holding".

One possible explanation for the gap between Revenue and BEA estimates of effective tax rates, and the examples shown in Table 1, is the use of taxable profits in Revenue data rather than a measure of pre-tax profits or accounting profits in BEA data. A major difference is that accounting profits use accounting based estimates of depreciation rather than depreciation calculated for tax purposes (Stewart, 1981 and 1987). Tax expenditures in the form of accelerated depreciation are important. One of the few increases in tax expenditures in the recent budget related to extending capital allowances for energy saving expenditures.

Finally the paper estimates the fiscal contribution from US multinationals at $€ 4.7$ billion for 2008 (about $11 \%$ of total tax). However, this includes tax collected by companies on behalf of the State, for example excise duties and VAT of $€ 1.4$ billion. It also includes tax on employees' incomes of $€ 698$ million. There may be some incidence effects but a more useful measure of economic value would be taxes paid as a direct result of economic activity such as corporation tax and local property taxes.

In conclusion this paper provides a very useful discussion of tax issues associated with foreign direct investment in Ireland.

\section{References}

Drucker, J. (2010), Google 2.4\% Rate Shows How \$60 Billion Lost to Tax Loopholes, Bloomberg, 21 October.

National Audit office (2007), HM Revenue and Customs Management of Large Business Corporation Tax, Report by the Controller and Auditor General, London: The Stationery Office, available at: http://www.nao.org.uk/publications. 
Stewart, J. (1981), "Effective Tax Rates on Profits", Paper read to the Social and Statistical Inquiry Society of Ireland, 2 April, 1981.

Stewart, J. (1987), Corporate Finance and Fiscal Policy in Ireland, Aldershot: Gower Publishing Company.

Stewart, J. (2011), Corporation Tax: How Important is the 12.5\% Rate, unpublished paper.

Yorgason, D. (2009), Collection of data on income and other taxes in surveys of U.S. multinational enterprises, Bureau of economic analysis, available at:- http://www.bea.gov/papers/pdf/Yorgason.

\section{SECOND VOTE OF THANKS PROPOSED BY JONATHAN HEALY, FORFÁS ${ }^{1}$}

It is hard to overstate the importance of the economic and trade ties between Ireland and the US. Both countries have benefited from this mutually beneficial relationship. I'd like to give you some statistics to illustrate this for the next few minutes, and I hope the majority of these are not already quoted in Keith's fine paper.

The US is Ireland's largest source of inward investment. In 2009, Ireland (through the IDA) secured 125 foreign direct investments, of which exactly two-thirds originated from the US. Analysed at a sector level, Ireland is the \# 2 location worldwide for US FDI in the ICT sector and fifth worldwide in chemicals. US affiliates in Ireland account for almost a quarter of Ireland's total output in 2009, compared with $6 \%$ in the UK and $<4 \%$ in Belgium. In 2009, US exports to Ireland were valued at $\$ 10.4$ billion, while Irish exports to the US totalled $\$ 39.2$ billion (or $\sim € 30.2$ billion). The range of US exports includes electrical components and equipment, computers and peripherals, drugs and pharmaceuticals, and livestock feed. Irish exports to the United States represent approximately $17 \%$ of all Irish exports and include alcoholic beverages, chemicals and related products, electronic data processing equipment, electrical machinery, textiles and clothing, and glassware.

Today, approximately 100,000 people are directly employed in over 600 US firms in Ireland. According to Forfás's 2009 Annual Employment Survey, this accounts for 70\% of all IDA-supported employment. In 2009, 355 of IDA's 660 FDI clients ( 54\%) are US-owned. Collectively, US companies have a $\$ 146$ billion ( $€ 112$ billion) foreign direct investment (FDI) in Ireland. This represents $8 \%$ of all US investment in the EU \& almost $5 \%$ worldwide. This equates to more than the total invested in the much hyped BRIC economies (Brazil, Russia, India, China); China, for example, received $\$ 46$ billion US FDI in 2008 (a third of the Irish figure). Irish companies directly employ an estimated 82,000 within 227 companies at over 2,600 locations in all 50 States across the US. The cumulative stock of Irish FDI in the US stood at $\$ 34$ billion in 2008. In 2009, US firms contributed $€ 3$ billion to the Irish Exchequer in taxes (including approximately 35\% of total corporate tax take) and they contributed $€ 15$ billion in expenditure to the Irish economy in terms of payrolls, goods and services employed in their operations. The IDA announced over 125 new and expansion FDI projects in 2009, creating almost 4,500 new jobs during. Of these positions more than 2,600 originated from US firms. Putting it another way, some two out of every three FDI projects coming to Ireland in 2009 have originated from the US.

$€ 500 \mathrm{~m}$ of investments were made in R\&D projects in 2009 , with over $€ 350 \mathrm{~m}$ of this originated from US firms. US firms in 2009 exported an estimated $€ 93.5$ billion of products and services from Ireland into world markets. The US is one of Ireland's top export destinations with total bilateral trade in the first three quarters of 2009 (exports to + imports from the USA) worth $€ 20$ billion. US firms in Ireland form a critical part of Ireland's cutting-edge, internationally traded goods and services economy in industries such as ICT, biotechnology, pharmaceuticals, medical devices and financial services. It is clear, therefore, that US investment has been critically important to the growth and modernisation of Irish industry over the past 25 years, providing new technology, export capabilities, and employment opportunities. In more recent years, Ireland has also become an important R\&D centre for US firms in Europe.

\footnotetext{
${ }^{1}$ Forfás, Wilton Park House, Wilton Place, Dublin 2. T: (01) 607 3273; E: Jonathan.Healy@,forfas.ie
} 
The question has been often asked: why do US companies come to Ireland? There are several reasons behind this. Many US businesses find Ireland an attractive location to manufacture for the EU market, since it is inside the EU customs area and uses the euro. US firms year after year account for over half of Ireland's total exports. Other reasons for Ireland's attractiveness include:

- a $12.5 \%$ corporate tax rate for domestic and foreign firms;

- the quality and flexibility of the English-speaking work force;

- co-operative labour relations;

- political stability;

- pro-business government policies;

- a transparent judicial system;

- $\quad$ strong intellectual property protection; and

- $\quad$ the pulling power of existing companies operating successfully (i.e. a "clustering" effect).

However, I would also like to mention the factors that negatively affect Ireland's ability to attract investment. These include:

- $\quad$ high labour and energy costs (especially when compared to low-cost countries in Eastern Europe and Asia);

- $\quad$ skilled labour shortages;

- $\quad$ inadequate infrastructure (such as in the transport and NGN/broadband sectors); and

- $\quad$ price levels that are ranked among the highest in Europe (especially for energy), although there have been some very significant improvements in cost competitiveness in the past two years.

The Irish Government actively promotes FDI, a strategy that saw total FDI stock grow from $€ 53$ billion in 1998 to $€ 131$ billion in 2007 . The Irish Government's actions have had considerable success in attracting US investment with a \$2.6 billion in investment inflow from the US during 2007. Up to the recent past, the principal goal of state investment policy has been employment creation, especially in technology-intensive and high-skill industries. More recently the Irish Government has increasingly supported efforts by foreign-invested companies to sustain their international competitiveness through R\&D enhancements, productivity improvements and the marketing and sales of higher-value goods and services.

Since 2005, Ireland has emerged as a magnet for US internet/digital media investment, with industry leaders Yahoo, eBay, PayPal, Google, Amazon, United Technologies, Hertz, LinkedIn and Facebook making the country a significant hub (or, indeed HQ) for their European operations. Ireland's evolution as a significant knowledge economy is evidenced in the sophistication and complexity of the investments into Ireland in recent times. These included investments in:

- Pharmaceuticals: Pfizer's new $€ 190$ million Biologics facility in Cork, and the commencement of construction on Merck Sharp \& Dohme's new plant in Carlow are leading examples;

- Medical devices: e.g. Boston Scientific announced a €91 million expansion of R\&D capabilities in Galway, while Alcon continues to grow their operations in Cork;

- Engineering: Clare-based manufacturing firm Microsemi announced a recruitment drive for 315 new employees in 2009;

- $\quad$ Food \& Drink: Coca Cola opened a new facility in Wexford in 2009;

- Financial services: 300 new jobs were created recently by Northern Trust in Limerick; and

- ICT: many high-profile investments - e.g.

0 internet firm Facebook has decided to locate its new international HQ in Dublin;

$0 \quad$ IBM invested $€ 25 \mathrm{~m}$ in the expansion of its software lab with the creation of 100 high-quality posts; and,

o Intel invested $€ 50 \mathrm{~m}$ in the expansion of R\&D facility in Clare with 134 jobs created.

The IDA has been recently targeting US FDI in emerging areas, including emerging convergence areas, such as: cloud computing, services innovation and cleantech. 
I warmly welcome Keith's paper on the economic and fiscal contribution of US investments in Ireland as it contains a wealth of useful data demonstrating the importance of Irish-American economic and enterprise ties. These ties need to be continually cultivated in an increasingly uncertain economic future. In this context, I would argue it is vital that strong efforts continue to be made in three areas of critical importance to the Irish business environment. These are crucially important for Irish indigenous enterprises, especially those exporting to foreign markets, but equally to overseas investors looking to potentially base operations in Ireland:

- We must retain Ireland's low corporation tax rate of $12.5 \%$; to alter this significantly would be anathema to Irish industrial policy and hugely deleterious for the Irish proposition to potential FDI clients;

- We must continue to improve national economic competitiveness via two crucial conduits: reducing further labour costs, and curbing and decreasing industrial energy costs.

- We must invest further in key infrastructural areas of strategic economic importance, such as the national electricity grid and in NGN technology, to ensure that a pipeline of high-valueadded FDI continues to flow into the country.

Ireland continues to be an attractive location for US firms to do business, and Ireland has reaped very significant economic benefits of a concerted strategy to attract US investment. We can no longer compete for low-end manufacturing, low-skilled FDI. Government has invested significantly in a transition to a so-called 'smart economy', and must continue to do so. In these high-end, high-skilled FDI opportunity areas,Ireland will need to now become a European, and indeed global, hub.

Table 1

\begin{tabular}{|l|c|c|c|c|}
\hline $\begin{array}{l}\text { Stock of US Investment in Ireland (Millions of } \\
\text { US \$; historical cost basis) }\end{array}$ & $\mathbf{2 0 0 4}$ & $\mathbf{2 0 0 5}$ & $\mathbf{2 0 0 6}$ & $\mathbf{2 0 0 7}$ \\
\hline All Industries & 63,983 & 55,173 & 71,065 & 87,023 \\
\hline Manufacturing & 12,619 & 11,979 & 12,567 & 19,180 \\
\hline - Food & 130 & 246 & $\mathrm{n} / \mathrm{a}$ & 34 \\
\hline - Chemicals & 2,438 & 2,378 & 3,494 & 6,202 \\
\hline - Metal & $\mathrm{n} / \mathrm{a}$ & 181 & 212 & 237 \\
\hline - Industrial Machinery & 293 & 204 & 295 & 340 \\
\hline - Computers/Electronic & 4,706 & 6,678 & 2,782 & 5,330 \\
\hline - Transportation Equipment & 58 & 44 & $\mathrm{n} / \mathrm{a}$ & 11 \\
\hline Wholesale Trade & -417 & 5,285 & 1,593 & 1,370 \\
\hline Information & 10,446 & 10,056 & 11,462 & 16,501 \\
\hline Finance/Insurance & 23,840 & 10,892 & 15,922 & 9,886 \\
\hline Holding Companies & 8,872 & 1,144 & 3,372 & 6,831 \\
\hline Prof. Services & 5,828 & 1,625 & 3,689 & 5,267 \\
\hline
\end{tabular}

Source: Bureau of Economic Analysis, 2009 
Table 2

US Companies Continue To Invest In Ireland During 2008

US Inward Investment Projects announced for Ireland during 2008

\begin{tabular}{|c|c|c|}
\hline COMPANY & LOCATION & ACTIVITY \\
\hline Abiomed & Westmeath & Manufacturing Expansion \\
\hline Aetna & Kerry & Expansion \\
\hline Alcon & Cork & Manufacturing Expansion \\
\hline Aon Group & Dublin & $\begin{array}{c}\text { New Center of Excellence to improve } \\
\text { efficiency }\end{array}$ \\
\hline Arris Group & Cork & R\&D Centre of Excellence \\
\hline Beckman Coulter & Galway & Research PhD funding with NUIG \\
\hline Boston Scientific & Galway & R\&D Expansion \\
\hline Business Objects & Dublin & Establishment of R\&D Centre \\
\hline Cameron & Longford & R\&D Expansion \\
\hline Channel Advisor & Limerick & New European HQ \\
\hline Citco & Cork & Expansion \\
\hline Citibank & Dublin & R\&D innovation facility \\
\hline Coca-Cola & Wexford & $\begin{array}{l}\text { New Manufacturing \& Innovation } \\
\text { Centre }\end{array}$ \\
\hline Cognex & Cork & Expansion \\
\hline Cook Medical & Limerick & $\begin{array}{l}€ 25 \text { million Expansion of current } \\
\text { operations }\end{array}$ \\
\hline CSN Stores & Galway & New EMEA HQ \\
\hline Cuna Mutual & Dublin & New European HQ \\
\hline DePuy & Cork & New Innovation Centre \\
\hline DTS Licensing Ltd & Limerick & New European HQ \\
\hline EMC & Cork & Investment in software development \\
\hline Eyewonder & Dublin & New European sales \& support centre \\
\hline Facebook & Dublin & Establishing an International HQ \\
\hline Freightquote & Dublin & Expansion European HQ \\
\hline Genzyme & Waterford & Expansion of manufacturing Operation \\
\hline Google & Dublin & Provisional European HQ Expansion \\
\hline GSK & Waterford & Manufacturing Expansion \\
\hline
\end{tabular}




\begin{tabular}{|c|c|c|}
\hline COMPANY & LOCATION & ACTIVITY \\
\hline IBM & Dublin & R\&D Partnership with Irish Universities \\
\hline IBM & Dublin & $\begin{array}{c}\text { Research project in network } \\
\text { development }\end{array}$ \\
\hline IBM & Dublin & $\mathrm{R} \& \mathrm{D}$ marine monitoring technology \\
\hline IBM & Dublin & Supply chain hub \\
\hline IVAX-Teva Pharma & Waterford & Manufacturing Expansion \\
\hline Lancaster Labs & Waterford & Service Support for Europe \& Asia \\
\hline Marriot & Cork & New operations centre \\
\hline Microsemi & Clare & Expansion of Operations \\
\hline $\begin{array}{c}\text { Netezza } \\
\text { Corporation }\end{array}$ & Louth & New European Operations Centre \\
\hline Nypro & Wicklow & Medical devices investment \\
\hline ON semiconductors & Limerick & New R\&D facility \\
\hline Option Wireless & Cork & Expansion \\
\hline PAFS & Limerick & New Shannon office \\
\hline Pfizer & Cork & Expansion \\
\hline ServiceSource & Dublin & New EMEA Headquarters \\
\hline Synoposis & Dublin & Expansion of R\&D capabilities \\
\hline ThermoKing & Galway & $\begin{array}{l}\text { New research into environmentally } \\
\text { friendly projects }\end{array}$ \\
\hline United BioSource & Dublin & New European office \\
\hline Unum & Carlow & New strategic software service centre \\
\hline Vistakon & Limerick & Manufacturing expansion \\
\hline $\begin{array}{c}\text { Wellman } \\
\text { International }\end{array}$ & Cavan & R\&D Investment \\
\hline Zimmer & Shannon & New manufacturing operations base \\
\hline
\end{tabular}

Source: IDA Ireland and the American Chamber Media Watch 